\title{
CONSTRUCTING A VOCATIONAL AND EDUCATIONAL TRAINING SYSTEM IN PERU DRAWING FROM SUCCESSFUL CASES IN THE ASIA-PACIFIC REGION
}

\author{
by \\ María del Carmen Nano Amburgo \\ A thesis submitted to the Victoria University of Wellington \\ in fulfilment of the requirements for the degree of Master of Commerce
}

Victoria University of Wellington

June 2019 

CONSTRUCTING A VOCATIONAL AND EDUCATIONAL TRAINING SYSTEM IN PERU DRAWING FROM SUCCESSFUL CASES IN THE ASIA-PACIFIC

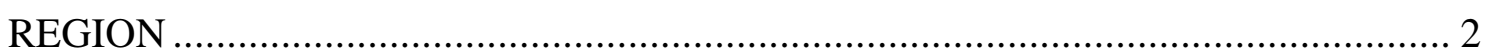

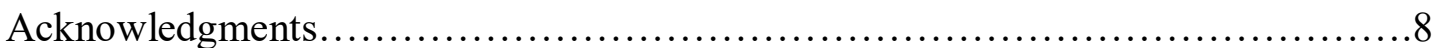

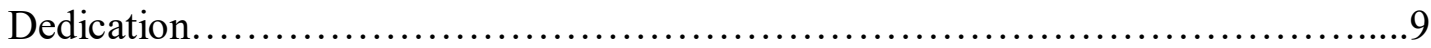

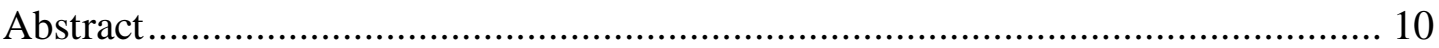

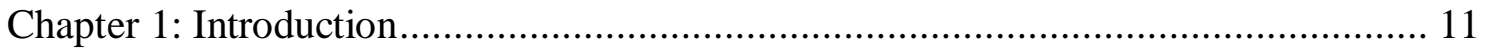

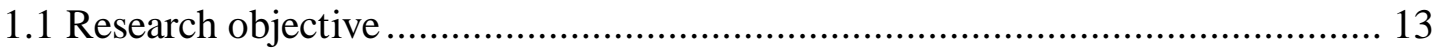

1.2 Methodology, research design and methods ............................................... 13

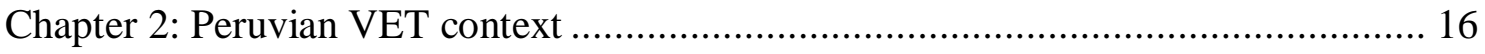

2.1 Structure and institutional actors in the Peruvian Technical Education System.. 16

2.2 The role of the Ministry of Education in the technical higher education

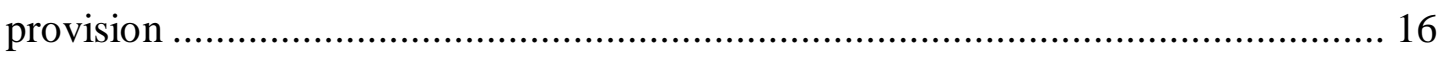

2.3 The Ministry of Labour and Employment Promotion .................................... 21

2.3.1 Joint initiatives between Educational and Labour Sector ......................... 22

2.4 The role of Ministry of Production: the connection between education and labour

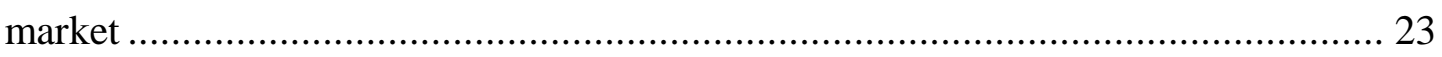

2.5 Peru's changing educational context and curriculums .................................. 27

2.5.1 Competencies-based approach in the NCBE and its connection with the

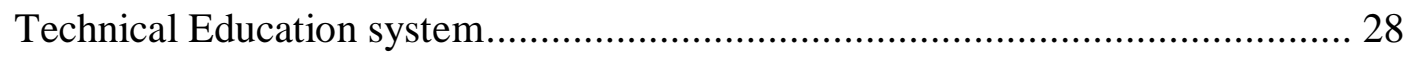

2.6 Vocational Education and Training in the Peruvian educational structure........... 31

2.6.1 Nomenclature of Vocational Education and Training ............................. 32

2.6.2 The International Standard Classification of Education (ISCED) and its equivalence with the Peruvian Education System.......................................... 33

2.6.3 Recommendations of the OECD to boost Peruvian public policies ............ 39

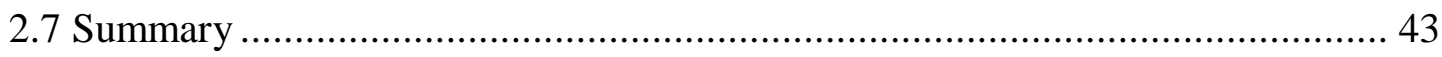

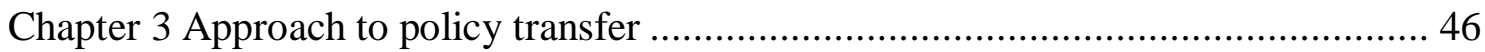


3.1 Peruvian past experience of policy transfer 46

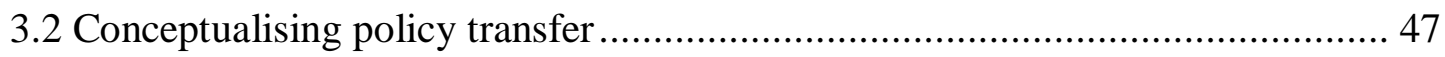

3.3 Growing influence of the Asia-Pacific Region in Peru ..................................... 51

Chapter 4: Learning from other VET systems .................................................. 54

4.1 Case study selection: global trends and indicators ...................................... 54

4.1.1 The Global Human Capital Report 2017............................................... 54

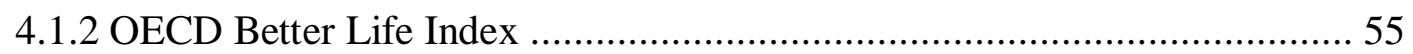

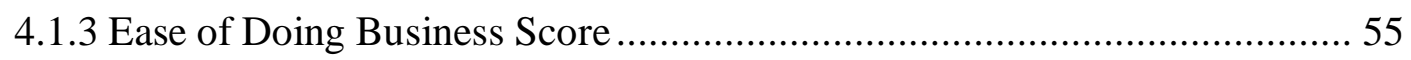

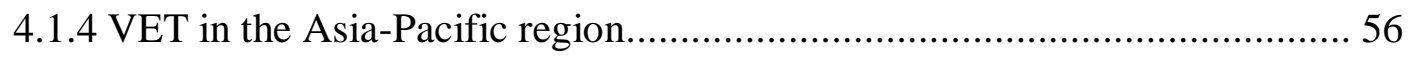

4.2 Institutional design of VET: the case of New Zealand, Australia and Canada.... 56

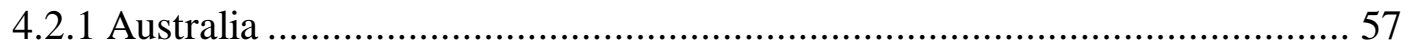

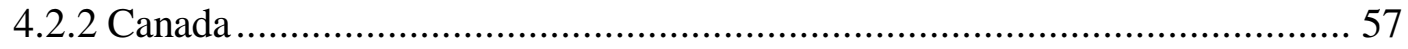

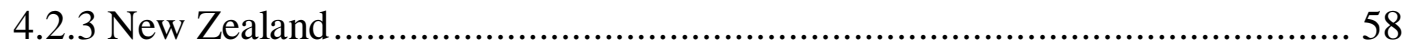

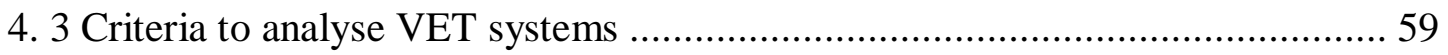

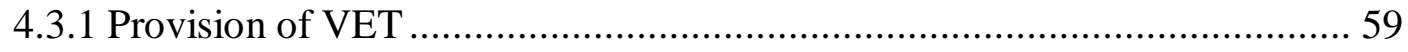

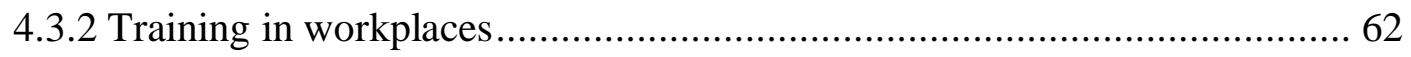

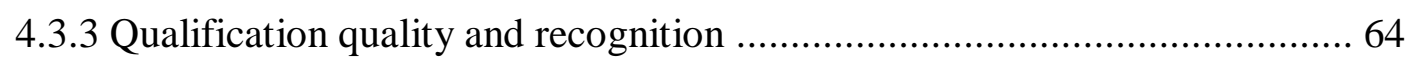

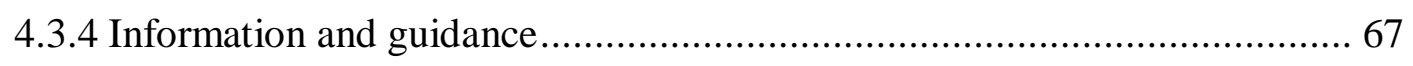

4.3.5 Improvement of governance and participation of the parties interested....... 70

4.3.6 Monitoring and evaluation .......................................................... 72

Chapter 5: A proposal to construct an effective VET system in Peru......................... 75

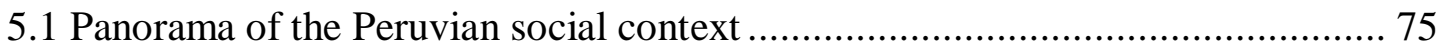

5.2 Improving the governance of VET education in Peru ................................... 76

5.2.1 Implementation of reforms in the Peruvian VET system: the case of CITEs

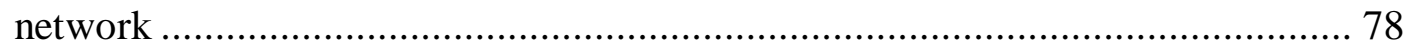

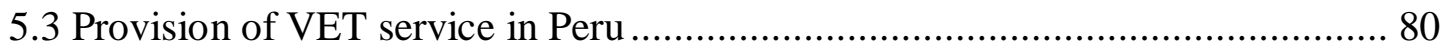

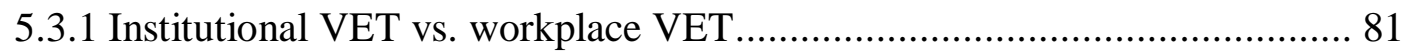


5.3.2 The transferability from non-university to university education

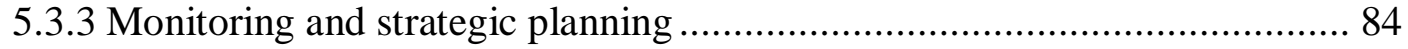

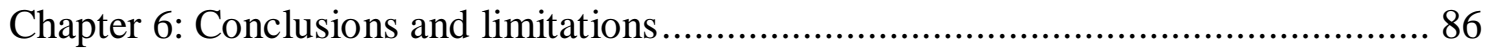

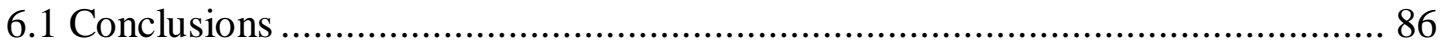

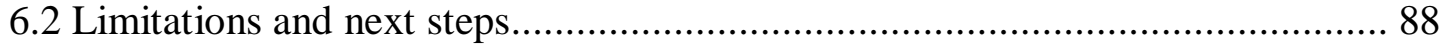

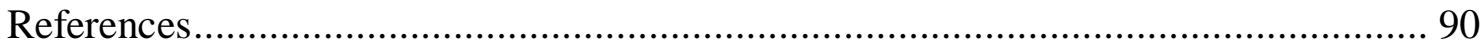

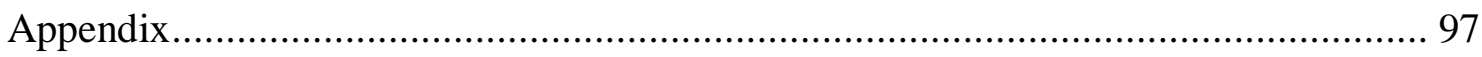

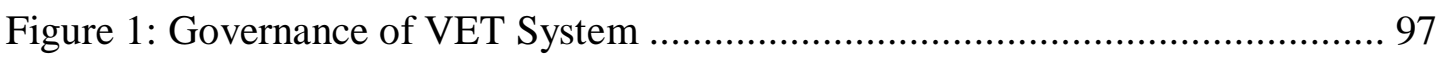

Figure 2: Peruvian Technical Education institutes............................................... 98

Figure 3: Proposal for a better governance of VET System .................................. 99

Figure 4: Proposal for an effective VET Peruvian system ..................................100

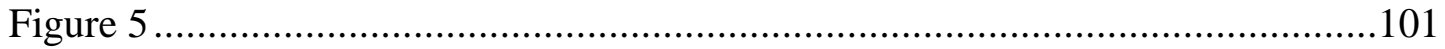

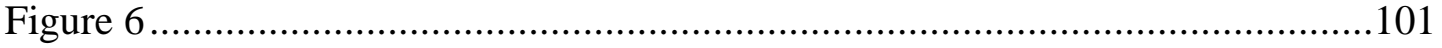

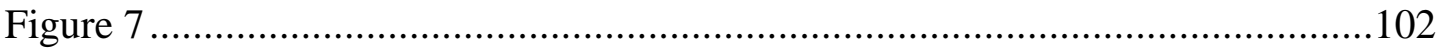

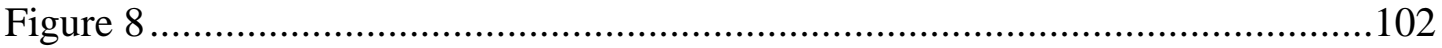





\section{Acknowledgments}

It is a genuine pleasure to express my deep sense of thanks and gratitude to my supervisor Elizabeth Eppel, for her meaningful assistance, tireless guidance and patience. Her timely advice, meticulous scrutiny and scientific approach have helped me to a very great extent to accomplish this task

I also owe my gratitude to Emeritus Professor Rowena Cullen and Professor Brad Jackson, former Head of School of Government, for their support to my research proposal four years ago.

I am extremely thankful to Dr. Flavia Donadelli, Associate Professor Graham Hassall and Professor Girol Karacaouglu, Head of School of Government, for their kind help and cooperation throughout my study period.

Special thanks to Victoria University of Wellington for granting me the Master's by Thesis Scholarship and the Latin American Academic Achievement Scholarship. Without this financial support this research would not have been possible.

Finally, I would like to thank Juan Villegas, former colleague and beloved friend, for helping me to gather important information to complete this thesis. 


\section{Dedication}

This thesis is dedicated to the memory of my father, who founded a transportation company from scratch and without any studies. His drive to succeed and natural talent for entrepreneurship is the most important legacy he let me and my brother. His sparkling personality and positive attitude towards life will always remain in my heart. 


\begin{abstract}
Peru currently has a fragmented and incomplete approach to Vocational and Educational Training (VET). This presents a problem for the country's growing demand for skilled human capital, specially the skills requirements needed to foster Small and Medium Enterprises' (SMEs) productivity. In a context where trends such as globalization, competitiveness and scientific and technological advances are setting big challenges to developing countries, it might be relevant that Peru gazes on best practices of those countries that have implemented recent reforms in their VET systems. This research uses a systematic approach to review the international literature on the design of VET policies and systems to discover the aspects which could be of use to Peru's next steps in the development of its VET system. It drew on the most relevant VET systems across AsiaPacific countries, such as New Zealand, Australia and Canada, to identify trends and define criteria to analyse the current VET system. Policy transfer frameworks are used to draw from these systems those characteristics most needed. Some of the most important policies that the Peruvian VET system might consider are to reduce the fragmentation of current VET system by bringing all the targeted programs that the Peruvian government is carrying out at present into a more integrated whole of government approach, the reform of formal provision of technical education at secondary and tertiary level that stress the transferability of degrees across the Asia-Pacific region, and the creation of a training system according to requirements of the labour market and socio-cultural characteristics of students.
\end{abstract}




\section{Chapter 1: Introduction}

Peru is a representative democratic republic considered a diverse and culturally complex country. It is located in South America and its territory is part of the "Tawantinsuyo", a region governed by the Inca civilization between the 12th and the 16th century. At the beginning of Peruvian independence from Spanish colonization in 1821, a series of internal conflicts plunged the country into a deep economic depression. In 1873, Peru embarked on a war over border issues. At that time and until the early twentieth century, Peru had a semi-feudal system in which indigenous peoples were confined to work on farms located throughout the country without any type of labour benefits. In that period, the Peruvian government adopted a series of political actions ranging from the claim of indigenous culture to the expropriation of large estates through agrarian reform (Mariategui, 1928). The residual effects of these events pervade a deep social and racial division that has survived until today.

Nowadays, Peru is facing significant challenges at the economic and social level. Some theoretical perspectives consider that Peru is still living a second stage of colonialism, this time justified by the Eurocentrism as a cultural model and buoyed up by capitalism (Quijano, 2000). These circumstances, plus the active classism, racism and other social scourges make Peru a fractured society that cannot yet trace a clear pathway for human and societal development.

Within this broad social context, Peru has focused its economic policy during the last twenty years towards opening up markets and attracting external investments. An indicator proof of the effectiveness of this strategy is that Peru was the only country in the region that reported a growing average rate of GDP of $6.1 \%$ between 2005 and 2014 (despite the economic downturn of 2009). This was in a large part thanks to the export of raw materials such as minerals (Harwood \& Konidaris, 2015). Moreover, between 1960 and 2010, Peru registered a productivity growth average of about 1.0 percent annual performance. This result positioned the country in the seventh place among 18 Latin American countries in terms of increased productivity during the past five decades (Vera, 2013).

However, this temporary and resource-based economic growth is not enough to achieve the longer-term well-being of a nation. According to several recent studies, such as the 
“Global Competitiveness Report 2012-2013” (Walker \& Aedo, 2012), for Peru to sustain productivity growth it is necessary to consolidate reforms in the areas of: strong public institutions, good education, good health services, infrastructure, and technology, among others. These are challenges Peru is still facing, especially in rural areas where it is particularly hard to effectively narrow social gaps.

Towards sustaining productivity growth, it is very important that the government develop a plan to implement policies to change the economy from one based on a primary-export model to a more diverse one. In this context, it is necessary to highlight the role of small and medium enterprises (SMEs), which represent the $99.6 \%$ of total Peruvian businesses, in a sustainable growth strategy. Indeed, the role of SMEs is quite relevant to how Peru evolves its economy towards a more sustainable model, as in today's world, SMEs are expected to be innovative, creative and competitive internationally, in order to benefit from Free Trade Agreements that the government constantly promotes (Choy-Zevallos, 2010). Moreover, in a context where science and technology are making impressive strides, SMEs face several challenges. For instance, the McKinsey Global Institute identifies four global forces affecting global market trends: a) the shifting of the locus of economic activity and dynamism to emerging markets; b) the acceleration in the scope, scale, and economic impact of technology; c) population ageing worldwide; and d) the high degree of connectivity in terms of trade, people, finance and data.

These global trends are likely to define the long-term prospects, especially for developing countries like Peru where the impact of changes, such as the demographic window phenomenon (Aramburú \& Mendoza, 2015), or the increasing use of telecommunication services (Fernández-Villares, 2013) are already evident. Likewise, the globalization process as a growing and inevitable trend brings with it a fierce competition for natural resources and the need to increase the commercial value of products within international trade. This demonstrates the need to build policies based on the "knowledge economy" undertaken by the countries to improve the human resources skills and capacities (De Jouvenel, 2015).

In this context, it is required to have a strong policy to create a skilled and adaptive workforce in Peru, specifically in terms of Vocational and Educational Training (VET), as this will contribute to meet the demands for skilled human resources of SMEs. However, the Peruvian VET sector is currently under-developed. In recent years the 
Peruvian budget for the education sector has been increased from $2 \%$ of domestic GDP in 2010 to $3.5 \%$ in 2015 . This budget is being invested mostly in educational infrastructure, intercultural education and information technology, as those were key and urgent areas that needed to be implemented. Meanwhile, in terms of vocational education policies, Peru has not had a sizeable change in the last decade. Despite this situation, according to the last School Census, there are 2,827 Technical Productive Education Centres and Institutes and Schools of Higher Education. These centres reported 634,181 enrolments, increasing at an average rate of 4\% between 2010 and 2014 (Linares-García, 2015).

There is a need to foster SMEs to export their goods and services, taking into account the global trends and the importance of diversifying markets. In order to achieve these aspirations, it is crucial to develop educational strategies and policies aimed to increase international competitiveness of small and medium enterprises as a way to further the welfare of Peruvian society. Therefore, I have focused my research on what Peru could do to build and improve its VET system to have a positive impact on SME's performance.

\subsection{Research objective}

The objective of this research is to examine the characteristics of a selection of Vocational and Educational Training systems for purposes of identifying those that might be applied to building a future-focused system to boost Peruvian SME's performance in the economy.

\subsection{Methodology, research design and methods}

My research drew generally on Pawson \& Tilley's approach to realist synthesis to identify key institutional design features of VET as revealed in the literature. (Pawson $\&$ Tilley, 1997). The identification of these features was used then to compare some actual country examples of VET systems from which Peru might learn. Thus, this research is focused on the comparative analysis of each country's VET system features, rather than the success of each system.

To conduct the research project, first it was necessary to describe the current situation of the Peruvian VET systems, its flaws and shortcomings, as well as the policies that 
might help to increase the system's effectiveness to boost SME's. The second part of my research required me to decide what factors to consider when proposing policy transfer. The research drew on policy transfer theory as a guiding framework for how this might be done. I then applied this policy transfer framework to the data I had collected from the chosen cases.

The first criterion for selection of suitable cases was geographical. My choice was to focus on the Asia-Pacific Region of which Peru is a member and relates economically. The second criterion for case selection was based on the maturity and performance of the VET system in the chosen countries but largely also, with the need to keep the number of cases for analysis manageable. The analysis of selected cases has then led to identify the characteristics of VET systems and how they contribute to well performing adaptive and innovative industry sectors in small developing economies. After this analysis, I proceeded to elaborate a proposition that could boost the current Peruvian VET system as a whole. Abstracting the selected cases in this way also allowed me to enable a comparative analysis across cases and an assessment of suitability in the context of Peru's existing economic development and education and training actors and institutions.

In order to conduct the research, I drew on a review of the literature on the role of VET in contributing to the productivity of SMEs. I identified a range of characteristics of VET systems that included the policy goals and drivers, the structural and institutional arrangements associated with vocational education and training systems, VET linkages across government, funding arrangements and the role of industry to name a few evident from preliminary reading.

To maintain a future focus, I used the work of Ewart Keep (2012), who states that VET policies need to be rethought in order to boost high-quality employment with the following three goals in mind: a) to change the structure of incentives and opportunity; b) to create a stream of policy and activity that helps to create decent work and more productive and innovative organisations; and c) to have a more realistic and better-designed set of skills interventions.

In addition to that, I reviewed international thinking and commentary from the OECD that focuses on learning and skills that the labour market needs, as well as the 
European Centre for the Development of Vocational Training (CEDEFOP). My review included also theoretical approaches about policy transfer in the public sector from D. Dolowitz, D. Marsh, M. Dussauge-Laguna, V. Mamadouh and E. Rubio Barceló, mostly. The intention was to identify which aspects and how they might be applied to the current Peruvian VET context. 


\section{Chapter 2: Peruvian VET context}

In this chapter I provide an overview of the current institutions, organisational landscape, provision, resourcing and relevant policies and programmes influencing vocational education and training (VET) in Peru. VET as such is not a term currently widely used in Peru, but in this section, I identify the parts of the current arrangements that might be identified as part of a VET system in an international terminology. I have decided to use the Spanish name of institutions and the programmes in many instances especially where names are not particularly meaningful when translated to English.

\subsection{Structure and institutional actors in the Peruvian Technical Education System}

The Government of Peru is composed of three branches, being the executive, judicial, and legislative branches. The Executive authority comprises eighteen ministries, three of them, the Ministry of Education, the Ministry of Labour and Employment Promotion and the Ministry of Production, have direct or indirect influence on technical education.

Fig. 1 shows the role of each institutional actor with the purpose of understanding how things stand in Peru's extant arrangements from the perspective of students. First, we have the Ministry of Education in charge of technical institutes and some targeted programs, next in the line is the Ministry of Labour, which has recently started to work with Ministry of Education and currently is running two targeted programs and committees. Finally, we have the Ministry of Production, currently unconnected with the Ministry of Education and the Ministry of Labour. In the next pages I will explain the legal role, objectives and current outcomes of each component of this system.

\subsection{The role of the Ministry of Education in the technical higher education provision}

The Ministry of Education, through the Department of Technical-Productive and Technological Higher and Artistic Education, is responsible for directing, coordinating, promoting, monitoring and evaluating technical-productive education and higher technological and artistic policies, as well as proposing legal documents 
within the scope of its competence. This Department has two directorates, one of which is the Directorate of Technical-Productive and Technological Higher and Artistic Education Services. This bureau is responsible for designing the policies, plans and legislation related to the regulation and promotion of the quality and relevance of education in its area of competence. It also promotes, systematizes and disseminates best teaching practices and innovation projects of the referred institutions (Ministerio de Educación, 2015).

The Ministry of Education monitors the running of higher education institutes and schools. The Institutes and Schools of Higher Education Act (Ministerio de Educación, 2016b) classifies these as:

- "Escuelas de Educación Superior" (EES) or Higher Education Schools. These educational institutions make up specialized people in the fields of teaching, science and technology, with an emphasis on applied training. They provide highly specialized theoretical training, with application of techniques to solve problems or propose new solutions. Its scope of study and action is specific within an area of scientific and teaching knowledge. EES can develop research and innovation projects as well. They also provide specialization studies, professional development in specific areas and other continuing education programs. There are 2 types of EES: "Escuelas de Educación superior Tecnológica - (EEST)" and "Escuelas de Educación Superior Pedagógica - (EESP) (Pedagogical Higher Education Schools).

- "Escuelas de Educación superior Tecnológica - (EEST)" or Technological Higher Education Schools. These link technology and applied sciences to the productive sectors of the national economy. They also provide specialized training with scientific foundation and the development of applied research. They are basically oriented to the domain of applied sciences, as well as the assimilation, disaggregation, adaptation, improvement and modification of technology and innovation.

- “Institutos de Educación Superior - (IES)” or Higher Education Institutes. They provide only technical training to achieve the skills required by the productive sectors for employment. They also offer specialized studies, 
professional development in specific areas and other continuing education programs.

EEST and EESP are subcategories of EES and both can offer education leading to a degree, while IES are a different type of institution and only teach and certify specific skills that the industry needs. In all cases, there are private and public providers, although the proportionality and ownership of IES and EEST appear not well balanced in respect of the number of publicly owned technical institutes and the learning places offered. This is a very important aspect regarding provision of educational service, as private institutions charge enrolment fees to the students and cannot be completely monitored by the government. As a consequence of this, there is no easily obtainable information about the quality of these private institutions or whether the fees are going directly to improve the provision of the service. A structure of this system can be viewed in fig. 2 .

According to the Educational Census 2017, the Peruvian population between 15 and 29 years of age was $8,440,802$, representing $26.5 \%$ of the total population. Within this group there are only 681,574 students enrolled in higher education institutes and schools across the country, from which 433,645 students are enrolled in EEST and 247,929 are enrolled in IES (see graphic 5). Regarding the number of students enrolled in the public and private system, we can appreciate that most students $(301,930)$ are concentrated in private EEST, while an appreciably smaller number of students are enrolled in private IES $(105,418)$. In the public system, the number of students enrolled in IES $(142,511)$ and EEST $(131,715)$ are almost proportional (see graphic 6). This means that there is a considerable proportion of students that are bearing the cost of their education because they access it through private education providers.

Overall, there are 2734 higher education institutes and schools across the country. In 2017 there were 1878 IES and 856 EEST (see graphic 7). Because IES outnumber EEST almost 2:1, the availability of training places in technical institutes linked to technology and applied sciences is considerably lower than the offer of places in institutions aimed to develop technical training for the industry. 
The disproportion between the offer of IES and EEST education continues when we compare IES ownership. The Educational Census 2017 registered 1552 private institutes, of which 1067 were IES and 485 were EEST, and 1182 public institutes, of which 811 were IES and 371 were EEST (see graphic 8). The large number of private IES is almost equal to the total public offer of technical institutes. In this regard, it is been demonstrated that the scarce availability of learning institutions with staff and equipment to teach skills most needed by the productive sectors of the economy has resulted in a perpetuation of an undersupply of places for vocational education and an oversupply of places offering traditional academic education (Guadalupe, Leon, Rodriguez, \& Vargas, 2017). We might say that the lower cost and high profitability of creating and managing IES might be the cause behind the currently large number of IES.

Further, it appears that neither EEST nor IES are managing to meet the needs of firms for skilled staff. In 2018, the Minister of Production Raul Reyes-Perez reported that from 24 thousand companies asked, $45 \%$ have problems in hiring technical staff (Rios, 2018b). In addition, the former Minister of Labour and Employment Daniel Maurate stated that $30 \%$ of young people between 18 and 24 years old who access higher education, most of them will study careers related to humanities and law, and only $18 \%$ of young people will study profitable careers that are linked to science, innovation and technology (Rios, 2018a).

A newspaper interview with Milton Chuquiruna, Head of the Department of General Studies of Tecsup, one of the most renowned IES in the country, stated that there are approximately 200,000 technicians missing per year in Peru (Diario Gestión, 2018). Indeed, only $17 \%$ of students that finish secondary school choose technical and engineering careers, and that percentage is lower if only technical careers are considered. Therefore, it appears that there is a shortage of technicians in the labour market, which means that the demand of those is larger than the offer of services provided by public and private EEST and IES.

It is also evident that the budget to boost technical education is not being directed to filling this gap. Almost the entire part of the resources that the Ministry of Education earmarked for the non-university higher education were focused on 
Pedagogical Higher Education. In 2015, the Ministry of Education earmarked a budget of S/. 8446 127.00 Peruvian Soles (USD 2,536,203.02) to technical higher education. In 2016, this budget was increased in S/. 8607 105.00 Peruvian Soles (USD 2,584,541.49), reaching its peak in 2017 with S/. 12870621.00 Peruvian Soles (USD 3,864,790.07). In 2018, the budget allocated to technical higher education is S/. 10092897.00 Peruvian Soles (USD 3,030,695.11) and represents only $0.19 \%$ of the total budget of the Ministry of Education.

Technical higher education has gained relevance over the last years due to the various governmental reforms implemented in the Education Sector. However, the reforms in this field have been oriented towards particular targeted actions, rather than a more comprehensive view of creating the technical higher education apparatus to work as a whole to meet needs. As a result, the organizational structure of technical schools has not change drastically over the last 20 years. Yet, one of the most notable recent reforms is the creation of EDUCATEC, a bureau that regulates the licensing, academic regime, management and supervision of the current offerings of technical institutes in Peru.

EDUCATEC is an autonomous body, part of the Ministry of Education, responsible for the technological higher education planning. Its aim is to apply current and emerging technologies and optimize the public training offer through reorganization processes (Ministerio de Educación, 2016b). EDUCATEC prioritizes the training to be funded and offered by IESs and EEST in response to the demands of the productive sector. In turn, IESs and public EEST develop their study programs within its different educational levels to meet the priorities identified by EDUCATEC.

According to the Regulation of the Institutes and Schools of Higher Education Act (Decreto Supremo No 010-2017-MINEDU), the planning of the educational offer to be funded by EDUCATEC must consider the following aspects:

a. Diagnosis of Technological Public Higher Education.

b. The plans and policies of the Ministry of Education, regional Governments and the sectors involved.

c. The local and regional needs of Technological Public Higher Education. 
d. The requirement of technical and technological professionals by the productive sector.

e. Linkage between educational offer and labour demand, current and future.

f. Definition of Higher Education offer awarded by IES and public EEST.

Through these functions and considerations for funding EDUCATEC is intended play a key role in the construction of a more responsive Peruvian VET system. It monitors and assesses institutions against the meeting of educational goals and objectives. I will return to the significance of this recent development of capability in chapter 5 .

\subsection{The Ministry of Labour and Employment Promotion}

The Ministry of Labour and Employment Promotion also plays a role in VET Education. It is responsible for the vocational and labour training through the Directorate of Vocational Training and Labour Training. Its functions are to propose and execute the policies, plans, programs and projects, both national and sectoral, in the field of vocational training, work training modalities, job training, work reconversion, vocational guidance and occupational information. It supports the development of mechanisms for the implementation and control of national and sectoral policies and regulations. It also contributes to the monitoring and evaluation of compliance with national and sectoral policies, plans, programs and projects, centralizes and systematizes the information coming from the regional and local scope and proposes and develops research and studies regarding its competence.

In 2018, this direction implemented two initiatives in terms of vocational guidance. The first is a web platform named "Proyecta tu futuro" or "Project your future", which provides information on training options and the situation of the labour market, tools to obtain and maintain a job such as vocational tests, multimedia information and testimonies of workers of actual workplaces. It should be noted that this platform offers an interactive search tool to find information about public and private IES and EEST per region and productive sector (Proyecta tu futuro, 2018).

The second initiative is referred to the "Competencies Committee". Its objective is to promote the improvement and development of employability, business 
competitiveness and labour productivity, helping to reduce the gap between supply and demand in the labour market with the direct participation of the main stakeholders from the Ministry of Housing, Construction and Sanitation, Ministry of Education, and the Ministry of Foreign Trade and Tourism (Diario Gestión, 2016). These forums identify and prioritize labour competencies needed by the different productive sectors. They also articulate labour performance standards with a view to creating processes of standardization of labour competencies, and the requirements of labour training and continuous training of the enterprises of the corresponding sector.

The Ministry of Labour earmarked a budget of 13,703,028.00 Soles in 2017 and $8,877,115.00$ Soles in 2018 for the generation of employment policies, professional and job training. However, I note that here is no specific budgetary goal in terms of vocational guidance or job training.

\subsubsection{Joint initiatives between Educational and Labour Sector}

As a result of the reforms implemented in the public sector over the last years, we have seen some recent joined-up government initiatives between the educational and labour sectors. We also see a lot of silo initiatives undertaken under the auspices of one agency and not necessarily well-linked to others. Some of EEST are mentioned in the following descriptions of the agencies and IES various initiatives directed toward VET.

The Ministry of Labour and Employment Promotion, the Ministry of Education and the Peruvian private organization "IPAE Acción Empresarial" joined in a strategic alliance to develop and implement the Observatory of Education and Employment called "Ponteencarrera.pe". This is a web platform that provides reliable and free information of the training offer and labour demand for the best decision making of Peruvian youth regarding IES professional future. "Ponteencarrera.pe". It has an application for smartphones as well and gathers a bunch of information based on different sources such as the National Institute of Statistics and Informatics, the marketing and data management company IPSOS Peru, Manpower Corporation, among others. The main source of information is the data reported by the Peruvian Higher Education Institutions through the "Information Collection System - SRI", while the information of the labour 
demand (remunerations by families of careers and institution) comes mainly from what is reported by the companies through the electronic payroll to the Ministry of Labour and Employment Promotion ("Ponteencarrera.pe," 2018).

\subsection{The role of Ministry of Production: the connection between education and labour market}

In order to understand the role of the Ministry of Production in Technical Education, it is helpful to see it in the light of the evolution of productivity in the country. Since the 1970s, Peru has been exporting raw materials such as minerals, agricultural products, oil and its derivatives, fishmeal and fishery products and light manufacturing mainly. This situation affects growth sustainability, as it renders the economy very vulnerable to price changes of exported goods in the global marketplace (Ministerio de la Producción, 2014).

Between 2003 and 2011, Peru and other exporting countries benefited from the growth of commodity prices. Since 2011, however, the price trend has reversed and begun to fall. This suggests an end to the high price cycle and a trend towards lower long-term prices and therefore slower economic growth. In addition, according to the IMF, Peru is the country that would suffer the greatest negative impact in the region due to the changing trends in the price of raw materials (International Monetary Fund, 2014).

Nowadays, productivity in Peru is concentrated in large but few firms. At the same time, there is a large group of micro, small and medium enterprises (MSMEs) that are not very productive. In addition, there are many unproductive sectors that cover a large part of the workforce while there are some very productive sectors that absorb fewer workers. There are also differences in economic performance between geographical areas and regions in Peru, which are naturally reflected in indicators of inequality (Ministerio de la Producción, 2014).

In this context, in 2014 the Ministry of Production launched a project to diversify the national productivity through a State strategy for the generation of new engines of economic growth. Under this, the "Plan Nacional de Diversificación Productiva" or National Productive Diversification Plan (PNDP) was created with the aim of promoting medium and long-term growth through the generation of a greater 
productive and transforming capacity, leading to diversification and economic sophistication, reducing dependence on prices of raw materials, improvement of productivity, increase in formal and quality employment, and long-term sustainable economic growth (Ministerio de la Producción, 2014).

The PNDP is composed of three dimensions and twelve lines of action. As part of the progressive execution of the PNDP, a restructuring of the Ministry of Production and its affiliated bodies was carried out. Thus, during the 2016-2017 period, the institutional regulations were modified, and new functions were created in accordance with the PNDP recommendations.

Currently, the Ministry of Production of Peru is comprised of two vice-ministries, of which the Vice Ministry of Micro and Small Enterprises and Industry covers SMEs, internal trade, promotion, development of cooperatives and industrial parks policies. It comprises five general directorates, of which three are involved in the improvement of Peruvian SMEs (Ministerio de la Producción, 2017).

The General Directorate of Policy and Regulatory Analysis is the body responsible for formulating and proposing national and sectoral policies and standards in the areas of micro, small and medium enterprises (MSMEs), industry, industrial parks, productive innovation and technology transfer, cooperatives and domestic trade; as well as the ordering of manufactured industrial products and controlled products (Ministerio de la Producción, 2017).

Likewise, the General Directorate of Business Development is responsible for proposing strategies for productive development and facilitating the access of MSMEs and associative modalities to business opportunities and business networks, fostering strategic alliances with public and private entities for the productive development of MSMEs, cooperatives and other associative modalities; monitoring the process of election of the representatives of the MSMEs in governmental entities, and proposing programs and instruments for the improvement of quality in MSMEs and associative modalities (Ministerio de la Producción, 2017).

Finally, the General Directorate of Innovation, Technology, Digitalization and Formalization is responsible for identifying trends in innovation and strengthening of entrepreneurship and business management through digitalization and 
formalization, with a focus on productive inclusion, decentralization and environmental sustainability, contributing to its competitiveness and productivity. It is also responsible for supervising the management of competitive funds linked to innovation, application of technologies for the productive sector, as well as for entrepreneurship and business management; and proposing and conduct the processes of monitoring and evaluation of the performance of the Centres for Productive Innovation and Technology Transfer (CITE) (Ministerio de la Producción, 2017). It is important to highlight that the coordination, orientation, and qualification of the CITE is overseen by the Technological Institute of Production (ITP). The ITP is an agency attached to the Ministry of Production that is competent in research, development, innovation, adaptation, transformation and technology transfer, with the purpose of achieving optimal use of resources to contribute to the increase of competitiveness of the production sector (Instituto Tecnológico de la Producción, 2016).

CITEs were conceived as decentralised organs in charge of contributing to the improvement of the productivity and competitiveness of the companies and the productive sectors through the activities of training and technical assistance, specialized advising for the adoption of new technologies; technological transfer, research, development and productive innovation and technological services, dissemination of information; interrelation of actors / strategic and generation of synergies, under a demand approach, generating greater value in the transformation of resources, improving the supply, productivity and quality of products for both, domestic and external market, promoting the productive diversification, according to the guidelines established by the Technological Institute of Production (Instituto Tecnológico de la Producción, 2016).

Currently, ITP is overseeing a CITE network composed by 46 centres all over the country. These CITEs are divided by geographical region and type of administration (public or private). It comprises the following productive sectors: Fisheries and Aquaculture, Agroindustry and Food, Clothing, Energy, Materials and Mining, Productive, Wood and Forestry, Marketing and Logistics, and Creative Industries. The initial investment in building and setting up new CITEs and refurbishing and upgrading the existent ones was $341,535,554$ Soles in total (USD 102,870,508.86). 
Currently, the annual budget for the implementation of CITEs is 73,200,762.00 Soles (USD 22,048,069.51), which represents only $20 \%$ of the initial investment.

Returning to the Peruvian Technical Education system and its connection with the productive sector, the PNDP establishes as part of its axis three named "Expansion of productivity" courses of action for "Adequacy of the training offer to labour demand". The PNDP states that the current offer of professionals does not meet the requirements of productive sectors. It also notes that the country has very few technical training entities able to provide training and qualification services that meet the requirements of companies. Moreover, it considers that the cause of this problem is the lack of reliable and timely information so that students, employers and training institutions can make better decisions. Thus, the PNDP has proposed joined-up government between the Ministry of Education and the Ministry of Labour and Employment Promotion.

To meet this objective, the actions proposed by the PNDP are (Ministerio de la Producción, 2014):

a) Streamlining the licensing process of institutes and careers in EEST and IES by reducing the processing time to 90 days, allowing more autonomy in curricular design and strengthening the monitoring and auditing systems.

b) Implementation of a National Professional Qualifications System, through the signing of at least 10 agreements between Sectorial Competences Committees and the industry sector. This will be a reference to Technical institutes for developing their educational curricula according to the required skills of the labour market.

c) Creation of the "Ponte en Carrera" Observatory, and

d) Improvement of infrastructure and management of EEST and IES with private investment through public-private alliances and the improvement of the current infrastructure regulation.

As explained above, the creation of EDUCATEC is an important step to improve the licensing process of EEST and IES. The Observatory "Ponte en Carrera" and "Project your future" has been implemented with aim of inform about the current 
opportunities in the labour market and how to develop skills and certify them, and the National Catalogue of the Educational Offer of Technical Productive and Technological Superior Education has been released in 2015.

\subsection{Peru's changing educational context and curriculums}

According to the OECD, educational advances in Peru in recent years have been significant. Spending on education as a percentage of GDP went from 2.9\% in 2010 to $3.7 \%$ in 2015 . However, there are challenges that still leave Peru below the educational results of OECD countries. Additionally, there is a significant gap between the skills of workers and those demanded by the labour market and reveals the difficulties of the education system to promote quality employability (OECD Development Centre, 2016). Moreover, Peruvian productivity has three main issues: a) productive heterogeneity; b) labour informality and c) lack of productive diversification. In short, the scarcity of technical skills is notorious as a gap in the current workforce policies (Comisión económica para América Latina y el Caribe y Organización Internacional del Trabajo, 2013).

Recent attempts have been made to address weaknesses in the current system. For example, a new Higher Institute Act was approved in 2016. This established for the first time the possibility that some of the technical schools could issue a first academic degree (bachelor's degree), based on an offer of programs that will be considered equivalent to those offered in university undergraduate programs (Guadalupe et al., 2017). Moreover, in 2016, and after a long process of dialogue and policy review, the Ministry of Education issued the updated National Curriculum of Basic Education (NCBE). The NCBE is the foundation of the Educational reform in Peru, and it is expected that helps to create better linkages between the different arms of the education system and thus contributing directly to better outcomes in the progression of learners. In accordance with the aims and principles of Peruvian education, the National Education Project and the objectives of Basic Education, this document established the main learning outcomes that students are expected to achieve, including those related to the transition of students from school to the labour market. 


\subsubsection{Competencies-based approach in the NCBE and its connection with the Technical Education system}

The recent move to a competencies-based approach within the NCBIE is also worthy of further consideration in respect of its connection to the technical education system. The NCBE offers an insight into how technical education is conceived in the Peruvian educational system. NCBE is based on 12 educational principles: quality, equity, ethics, democracy, environmental awareness, interculturality, inclusion, creativity and innovation, as well as gender equality and sustainable development. Likewise, it contains seven transversal approaches: inclusive or attention to diversity, rights approach, interculturality, gender equality, environmental approach, orientation to the common good and pursuit of excellence. Moreover, it defines the competencies, capacities, learning standards and performance that every student must accomplish.

Through the NCBE, Peruvian educational system is proposing a competenciesbased approach. It is important to notice that the term "competencies" has two etymological roots: one of them comes from Linguistics and the other from the labour market. Thus, the definition of "competencies" might have a utilitarian meaning in the world of work, where it is conceived as a strategy that relies on the analysis of tasks, from which it is sought to determine the specific stages in which must train an average technician (Diaz-Barriga, 2005).

The competencies approach refers to the idea of meaningful learning, where the notion of competency has multiple meanings, all of which present four characteristics in common: competence considers the context, is the result of an integration process, is associated with execution or performance criteria and implies responsibility. The challenge of educational reforms is how the new society solves the need for equitable distribution of knowledge, what characteristics such knowledge must have in order to be 'socially valid' and how is it organized the social environment to make possible the 'lifelong learning' (Aguerrondo, 2009).

Despite all the criticisms that exist regarding this competencies-based model, we can say that a competencies-based education is more open to incorporate the 
technical education as an essential part of the system. Likewise, we need to have in mind the existing educational perspectives regarding competencies. Currently, we can find a wide variety of them in literature, which can be classified as follows:

- Behavioural perspective. It defines competencies as key behaviours of people to boost organizational competitiveness. It has an empiric-analytic focus or neopositivist.

- Functionalist perspective. It considers competencies as attributes that people must have to fulfil the purposes of labour-professional processes framed in defined functions.

- Constructivist perspective. It defines competencies as knowledge and skills to solve difficulties in labour-professional processes from the organizational framework.

- Complex perspective: It defines the competencies as complex processes of performance in activities and problems with suitability and ethics, looking for personal accomplishment, quality of life and sustainable social and economic development and in balance with the environment.

The complex perspective challenges the classical ideal of linear, deductive rationality. While the ideal of the simplification of a task into component parts belongs to classical rationality, the complexity perspective understands the world in terms of dynamic systems where the interactions between the constituents of the systems and their environment are as important as the analysis of the components themselves (Aguerrondo, 2009). In times of change and uncertainty, to apply a complex perspective in the teaching process means to ensure that students reach a holistic view of reality, and for that to offer them the cognitive, affective and behavioural means that this global and complex vision implies (Santos-Rego, 2000).

In the case of the Peruvian educational system, the NCBE sets 29 competencies with eight standards for each competency, based on a complex perspective. Regarding this, the "Instituto Peruano de evaluación, acreditación y certificación de la calidad de la educación básica - IPEBA" states in its report called "Learning standards: What are we talking about?" that the "complex thinking" is one of the main aspirations in Peruvian education (IPEBA,2011). It is important to highlight 
that this report consists of a review of international literature and comparative experiences of Australia, Chile, Colombia, Guatemala, and United Kingdom that helped to develop the technical and methodological proposal of the national standards, and the foundations of the current NCBE.

The NCBE addresses technical education within Competency 27 called "Managing projects of economic or social entrepreneurship", which defines as follows:

Competency 27: "Managing projects of economic or social entrepreneurship" It means that students undertake a creative idea by mobilizing efficiently and effectively its resources, tasks and techniques to achieve individual and collective objectives and goals, in order to solve an unmet need or an economic, social or environmental problem. Also implies that the student works cooperatively to create a value proposition, capturing a solution alternative to a need or problem of their environment, through a good or service, validate their ideas with possible users and select, depending on the pertinence and viability; design the strategy that allows you to implement it by defining resources and tasks required, apply technical skills to produce or provide the good or service devised and evaluate the processes and results in order to make decisions to improve or innovate.

This competence involves the combination of the following capabilities:

- Creates value proposition: generates creative and innovative solution alternatives through a good or service that solves an unmet need or an economic, social or environmental problem that investigates in their environment; evaluates the relevance of their solution alternatives validating their ideas with the people they seek to benefit or impact, and the feasibility of the solution alternatives based on criteria for select one of them; design a strategy that allows you to start your idea defining objectives and goals and sizing resources and tasks.

- Work cooperatively to achieve goals and objectives: integrate individual efforts to achieve a common goal, organize teamwork based on the different skills that each member can provide, take responsibility for their role and the tasks involved 
in carrying out effectively and efficiency. It is also reflecting on their work experience and that of the team members to generate a favorable climate, showing tolerance to frustration, accepting different points of view and agreeing ideas.

- Applies technical skills: it is to operate tools, machines or software programs, and develop methods and strategies to execute the production processes of a good or the provision of a service applying technical principles; it involves selecting or combine those tools, methods or techniques according to specific requirements applying criteria of quality and efficiency.

- Evaluates the results of the entrepreneurship project: it is to determine to what extent the partial or final results generated the expected changes in the attention of the problem or identified need; uses the information to make decisions and incorporate improvements to the design of the project. It is also to analyse the possible impacts on the environment and society and formulates strategies that allow the sustainability of the project over time.

As we can see above, this competency conceives technical education as a means to boost entrepreneurship. This is a pertinent approach, considering that it is the first time the Peruvian educational curriculum links technical education and industry. We can consider this change as a good starting point for developing a more comprehensive Vocational an Educational Training system in Peru.

\subsection{Vocational Education and Training in the Peruvian educational structure}

Prior to unfolding the main directions of changes in the Peruvian educational structure, we locate vocational educational and training within the system using an accepted international framework. This is deemed useful for identifying the shortcomings in the current system, as well as to facilitate its comparison with other VET systems. 


\subsubsection{Nomenclature of Vocational Education and Training}

Several international organizations dedicate efforts to developing studies related to the Vocational Education and Training (VET). For instance, UNESCO define it as those aspects of the educational process involving, in addition to general education, the study of technologies and related sciences, and the acquisition of practical skills, attitudes, understanding and knowledge relating to occupations in various sectors of economic and social life (UNESCO, 1984).

The International Labour Organization (ILO) defines the VET as the education and training beyond compulsory education, but excluding degree-level programmes, which provides individuals with occupational or work-related knowledge and skills (ILO, 2006).

The European Centre for the Development of Vocational Training (CEDEFOP) defines VET as the education and training which aims to equip people with knowledge, know-how, skills and/or competences required in particular occupations or more broadly on the labour market (European Centre for the Development of Vocational Training (CEDEFOP), 2008). While the European Union Commission defines the VET as the training in skills and teaching of knowledge related to a specific trade, occupation or vocation in which the student or employee wishes to participate. This type of education may be undertaken at an educational institution, as part of secondary or tertiary education, or may be part of initial training during employment, for example as an apprentice, or as a combination of formal education and workplace learning (European Union Commission, 2016).

The United Nations Economic Commission for Latin America and the Caribbean (ECLAC) uses the term "Professional Technical Education (PTE)" and defines it as an educational modality that combines the theoretical and practical learning relevant to a specific occupation or occupational field, distinguishing between initial and continuous PTE. The first includes formal programs at the secondary and higher levels, designed to be taught to young people at the beginning of their professional careers and prior to entering the labour market. Continuing education, on the other hand, includes the rest of the programs, including the 
training of employees in companies and training specifically aimed to the unemployed (Sevilla B. \& Trucco, 2017).

According to the OECD, it is important to set up an international branding for this aspect of education as, in an increasingly globalised labour market, this tangle of nomenclature might discourage some good quality but less well-recognised vocational programmes and qualifications. Moreover, an international branding is helpful not only to those who wish to use their qualifications in other countries, but also in international enterprises where the nuances of national qualifications will be confusing to define skills and capacities of expatriates. Therefore, the OECD proposes "professional education and training" as an internationally accepted nomenclature that describes substantial post-secondary vocational programmes equivalent to more than six months full-time (OECD Reviews of Vocational education and training, 2014).

In this research, I have elected to use the Vocational Education and Training nomenclature. The reason is that, despite the suggestions of the OECD and other supranational organisations, most of the literature about this topic still uses the VET nomenclature.

\subsubsection{The International Standard Classification of Education (ISCED) and its equivalence with the Peruvian Education System}

Further, in terms of the transparency of learning outcomes in VET and the portability of that learning across different employers, sectors and countries, the role of the International Standard Classification of Education (ISCED) needs elaboration. ISCED is adopted by the General Conference of UNESCO member states. It is designed to serve as a framework to classify educational activities as defined in programmes and the resulting qualifications into internationally agreed categories. The basic concepts and definitions of ISCED are therefore intended to be internationally valid and comprehensive of the full range of education systems (UNESCO Institute for Statistics, 2012).

The last ISCED report was issued in 2011 and developed three components: i) internationally agreed concepts and definitions; ii) the classification systems; and iii) ISCED mappings of education programmes and related qualifications in 
countries worldwide. Regarding the classification system of educational levels, ISCED considered the following structure: 
Table 1:

ISCED Classification (2011)

\begin{tabular}{|c|l|}
\hline \multicolumn{2}{|c|}{ ISCED-Programmes } \\
\hline 0 & Early childhood education \\
\hline 1 & Primary education \\
\hline 2 & Lower secondary education \\
\hline 3 & Upper secondary education \\
\hline 4 & Post-secondary non-tertiary education \\
\hline 5 & Short-cycle tertiary education \\
\hline 6 & Bachelor's or equivalent level \\
\hline 7 & Master's or equivalent level \\
\hline 8 & Doctoral or equivalent level \\
\hline 9 & Not elsewhere classified \\
\hline
\end{tabular}

Source: UNESCO, 2012

According to this classification, the orientation of a programme is distinguished at ISCED levels 2 to 5, with the possibility of use at ISCED levels 6 to 8. ISCED considers two categories of orientation:

Vocational education is defined as education programmes designed to acquire the knowledge, skills and competencies specific to a particular occupation, trade, or class of occupations or trades. Such programmes may have work-based components like apprenticeships or dual-system education programmes. Successful completion of such programmes leads to labour market-relevant, vocational qualifications acknowledged as occupationally-oriented by the 
relevant national authorities and/or the labour market (UNESCO Institute for Statistics, 2012).

General education is defined as education programmes that are designed to develop learners' general knowledge, skills and competencies, as well as literacy and numeracy skills, often to prepare participants for more advanced education programmes at the same or a higher ISCED level and to lay the foundation for lifelong learning. These programmes are typically school- or college-based. General education includes education programmes that are designed to prepare participants for entry into vocational education but do not prepare for employment in a particular occupation, trade or class of occupations or trades, nor lead directly to a labour market-relevant qualification (UNESCO Institute for Statistics, 2012).

Regarding the Peruvian Educational system, there are three types of technical education: a) Technical-productive Education; b) Technological, pedagogical and artistic and c) High schools that offer an academic degree. In the table below, we can usefully see how it is built and its equivalence with the ISCED model. 
Table 2:

Structure of Peruvian Educational System (2018)

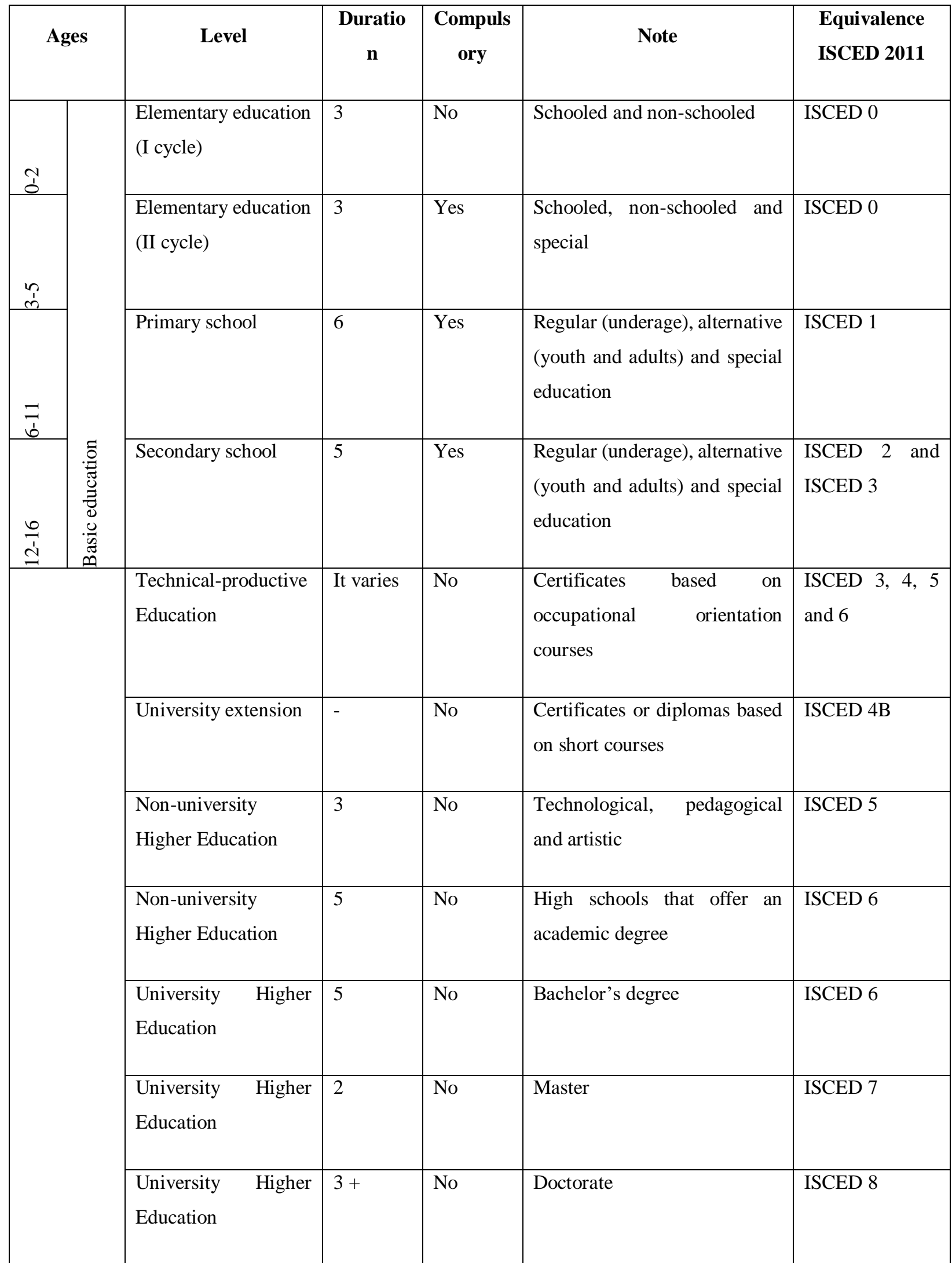

Source: GRADE (2017) 
From the above exposition it can be seen that Technical-productive education is outside the basic education system. However, at Secondary School there are 2 pedagogical hours per week dedicated to the course named "Work-oriented Education". The purpose is that students increase IES professional career opportunities through the development of skills that strengthen and ensure IES employability. To meet this objective, the NCBE integrates the productive technical development with a focus on the development of complex design skills, economic and social management, evaluation and innovation, and socioemotional skills, with the aim of providing basic education students with necessary skills to display IES potential and achieve IES professional and labour goals (Ministerio de Educación, 2016a).

Regarding the post-secondary level, the Regulation of Act No 30512 named "Act of Institutes and Schools of Higher Education and the Teachers' Public Career" defines four training levels within the Technical-productive education (Ministerio de Educación, 2017). These are:

a. Technical Assistant. It develops study programs with a minimum of forty (40) points. Applies to EEST and IES. At this level students can perform predetermined or simple operations of the productive process of goods or services, under supervision and according to established procedures. Also, they can report technical problems that arise and ask about corrective actions. A student who graduates from this level can enter the labour market or continue with the technical level, as long as it is a career linked to an economic activity.

b. Technical level. This level develops study programs with a minimum of eighty (80) points and applies to EEST and IES. At this level students can control IES own tasks, develop supervision over IES activities, identify technical problems and execute specific corrective actions. A student who graduates from this level can enter the labour market, deepening IES knowledge in the technical field or continue with the technical level of technological higher education, provided that it is a career linked to an economic activity.

c. Technical-Professional Level. This level develops study programs with a minimum of one hundred and twenty (120) points and applies to EEST and IES. 
At this level, students can perform processes and procedures of predetermined work with limited autonomy, supervising the activities and tasks of workers under IES charge, and calculate the technical and material resources required in the production of goods or services. A student who graduates from this level can enter the labour market, deepening IES knowledge in the technical field or continue IES training at higher levels.

d. Professional level. This level develops study programs with a minimum of two hundred (200) credits and applies to EEST. At this level, students can organize, carry out and supervise the activities and tasks of people under IES responsibility with autonomy and decision-making capacity, and calculate the technical and material resources required in the production of goods and services. A student who graduates from this level can enter the labour market, deepening IES knowledge in the technical field or continue IES training at higher levels.

At the end of EEST training levels, students can be awarded a certificate or degree, such as Technical bachelor's degree, Technical Degree and Technical Professional Degree. This system places Technical Professional Degree from IES, EEST and bachelor's degrees from universities at the same level (ISCED 6). Regarding transferability between technical education and university higher education, the regulations only allow students to validate courses taught in secondary school, certification of skills and training level's certificates to shift to another study programme within EEST or IES. However, in the case of universities validation is possible through use of the point system in higher education (La República, 2016).

\subsubsection{Recommendations of the OECD to boost Peruvian public policies}

In recent years, the Peruvian government, in coordination with the Organization for Economic Cooperation and Development (OECD), has initiated the "Country Programme": a gap analysis and policy recommendations work on major issues to improve. The objective of the programme is to facilitate Peru's admittance as a full member of the OECD by 2021. In this regard, in 2016 the OECD issued a report named "A Skills beyond School. Review of Peru", as part of the OECD Reviews of Vocational Education and Training. 
According to this report, Peru offers very little vocational education and training at the secondary level, as recent educational reforms reduced the number of hours that schools could dedicate to "education for work" and required the small group of vocationally oriented upper secondary schools to increase their academic offerings. The result was to put these schools on par with other traditional secondary schools. Because of this, while secondary enrolments have risen significantly over the last two decades -from just $55 \%$ of children aged 11 to 17 to $76 \%$ - it has not resulted in an increase in access to vocational or work-related skills for secondary students (McCarthy \& Musset, 2016).

In addition, the OECD considers that the system is oversupplying graduates from less technical fields and under-supplying graduates in more rigorous science and technology fields, causing employers have difficulties finding workers with technical skills because of weak connections between the content of educational programmes and the needs of the workplace (OECD, 2014b).

To solve these failures, the OECD made 15 recommendations to improve the Peruvian VET system (McCarthy \& Musset, 2016):

1. Provide targeted and performance-based funding to private institutions that successfully graduate students in programmes with demonstrated labour shortages.

2. Strengthen and expand data systems that connect education and labour market outcomes and track student transitions within education and into employment.

3. Allow more flexibility in the delivery of the national curriculum to permit institutions to meet the needs of local economies and employers.

4. Continue efforts to develop an effective accreditation system for VET institutions and programmes.

5. Strengthen public VET institutions through increased funding for equipment, faculty development, and professional management.

6. Require mandatory work-based learning (WBL) opportunities for all VET students.

7. Build the capacity of IESs and EEST to support student transitions through articulated programmes of study, dual enrolment policies, and outcomesbased funding formulas. 
8. Continue developing a national qualifications framework that clarifies and rationalises the distinct qualifications awarded by academic and technical institutions, including those that operate outside the jurisdiction of the Ministry of Education.

9. Build the capacity of IESs to issue secondary qualifications in order to facilitate transitions into postsecondary and tertiary education for their graduates.

10. Through partnerships with sectorial schools and strategies like dual enrolment and programme articulation with EEST, develop upper secondary vocational opportunities of high quality.

11. Expand targeted scholarship programmes and other forms of financial aid to low-income students pursuing postsecondary VET.

12. Strengthen and expand opportunities for adults to access affordable and highquality vocational programmes.

13. Continue expanding and improving Pontencarrera.pe and other consumerfacing tools that help build awareness about labour market trends and opportunities, as well as the cost and returns of particular programmes.

14. Invest in the professional development of school-based career counsellors and train them in the use of labour market data.

15. Leverage the sectorial groups and the CITEs to partner with secondary schools and job centres to provide information on careers and local job opportunities.

OECD found that Peru has an extensive and highly fragmented technical educational sector, which is poorly connected with traditional academic institutions. Distinct governance structures, regulatory policies, and funding models generate significant differences in quality among institutions and can make it difficult for students to move smoothly along educational pathways (McCarthy \& Musset, 2016).

According to the OECD, the rapid pace of technological change complicates the alignment of the supply of education with a constantly changing workplace. The balance between technical and soft skills is hard to find as workers need to be able to operate current technologies but also adapt quickly to new ones. An evidence of this is that of the nearly 2 million Peruvians with technician-level degrees, only 
$15 \%$ work as technicians, while the others work in jobs that do not require specific job skills, which indicates that the system does not meet the needs of the labour market (McCarthy \& Musset, 2016).

One of the main characteristics of the Peruvian VET system as we saw in Chapter 1 , is that it is dominated by private providers. In this context, the OECD recommends the design of public policies that rewards institutions for aligning their programmes with the broader needs of the economy and long-term interests of students. Because of this, the OECD considers that it is essential for government to build a policy infrastructure to ensure that providers respond to the right set of demand signals, otherwise, in the absence of public policies that structure the market, schools would focus on student enrolments rather than employer demand, leading to sub-optimal outcomes for both (McCarthy \& Musset, 2016).

As mentioned above, the OECD states that Peru lacks an adequate set of policies to build quality in VET and ensure consistency across programmes and providers. On the one hand, the strong reliance on private providers that operate with considerable operational autonomy limits the ability of the government to shape how programmes are delivered. On the other hand, the low level of investment in public VET institutions constrains their ability to keep up with industry practices. The segmentation of the VET market between those governed through Ministry of Education in Peru and those under other distinct arrangements further complicates efforts to build a common understanding around programme quality. As a result, there is wide variability in the quality of particular programmes, which hurts both students and employers (McCarthy \& Musset, 2016).

Finally, the OECD highlighted the importance of mobility across vocational and academic institutions and the implicit guarantee of opportunities for upskilling, as it has an impact on the student's choice between academic and technical programmes: prospective students would be more willing to engage in shorter VET programmes if they know that such programmes provide an effective basis for more advanced studies (McCarthy \& Musset, 2016). 
Regarding the role of CITEs in the Peruvian VET system, the OECD notes the importance of these centres, as CITEs operate across a variety of industry sectors with the goal of helping Peruvian businesses move up the production value chain and meet international standards necessary to take full advantage of trade agreements and global supply chains. Improving the skills and abilities for Peruvian industry sectors is a central concern of the CITEs, which should work with a variety of EEST and universities on curriculum and programme design (McCarthy \& Musset, 2016).

Having in mind these recommendations, as well as my own observation of institutional fragmentation set out in previous sections, leads to the question what policy lessons might Peru draw from other well developed VET systems in order to carry out an effective Peruvian VET system reform. Aspects of system design gleaned from other countries could take the form of criteria to help Peru seek best practices in other countries and how their experience can be transferred or adapted to the Peruvian reality.

\subsection{Summary}

Across this chapter we have built up a picture of the current institutional and policy landscape of the VET system in Peru. A positive feature is that the NCBE includes entrepreneurship as a competency in basic education and prepares students for a possible career as technicians or entrepreneurs. Moreover, the fact that each training level awards a certificate or degree to students is very promising for reducing the shortage of technicians in the labour market in a short period of time. The creation of EDUCATEC is also a big asset to build a strong VET system and it could constitute a key component of it in the future.

However, there are important limitations. For instance, we can appreciate a high level of siloed bureaucracy in the current system. There are three ministries, eight departments, two targeted programs and more committees involved in this whole process. The level of institutional fragmentation keeps the various system actors unconnected, and the targeted programmes might be overlapping tasks. An absence of any formal co-ordinating governance mechanisms to bring together the policies and actions of these ministries and agencies is also noted. 
In addition, the technical-productive education has been designed as a separate system from the university higher education which has its own degrees and is largely unconnected to the schooling sector in ways that would create progressions through and across the system. The current system offers reduced flexibility to students in case they want to validate their degrees in an international system for possible job or training opportunities abroad. Regarding the productive sector, despite the high investment in the construction of the CITEs network, the shortage of human capital is the biggest bottleneck to improving SMEs' performance. This might be attributable to the disconnection between the Ministry of Production and the other two ministries.

These limitations are hindering the Peruvian government from accomplishing the goals stated by the OECD in terms of education. Therefore, the government might need to consider implementing reforms that connect the various parts of the VET system, to improve its governance and effectiveness. We will discuss possible solutions along these lines in chapter 5 . 



\section{Chapter 3 Approach to policy transfer}

Having set out the context for the research problem and some themes from my review of the VET literature that could be considered relevant for Peru in the previous two chapters, I now turn to the concept of policy transfer. This chapter firstly argues for my selection of the policy transfer concept as my theoretical lens for analysis of cases from which policy might be transferable to Peru. It then provides a critical analysis of the Peruvian experience to date in terms of policy transfer, especially in the education field. I consider a theoretical framework that explains the different situations in which such transfer might be successful and how this might be applied in the Peruvian context. Finally, I explain the Peruvian government's prioritization of its foreign affairs with the Asia-Pacific region and consequentially the importance of this context for identifying countries and their VET policies for transfer to Peru.

\subsection{Peruvian past experience of policy transfer}

According to Pasi Sahlberg, educational structures in any country are, to some extent, a result of cultural, historical and social determinants and hence often difficult to understand in isolation from those contexts (Sahlberg, 2007). In the case of Peru, there is a record of educational policy transfer during the $20^{\text {th }}$ century that confirms this. During the government of Augusto B. Leguia in the 1920s, not only the Education sector but all the governmental institutions were assisted by North American consultants. Indeed, the final objective of President Leguia was to put specialists from United States at the helm of each Peruvian institution (Klarén, 2004).

In this context, Act No. 4004 of educational reform was issued in 1920. This law was based on the work of the Commission created by the government in 1910, which was presided by Manuel Vicente Villaran and counselled by Harry Edwin Bard, director of the first US mission in Peru (Marrou Roldán, 2012). This law was basically aimed to provide free and compulsory basic education and to promote the education of the inhabitants of the mountains in line with their particular socio-cultural and demographic characteristics (Marrou Roldán, 2012). It proposed an education for the upper class, and inclusive of the middle and popular classes (Morillo, 2000). However, according to many Peruvian intellectual thinkers, this law served as a pretext to benefit the wealthy class, to maintain the status quo and the social system 
established by the ruling class. For instance, Jose Carlos Mariategui points out: "It is not possible to democratize the education without democratizing its economy and its political superstructure (...) the reorganization of education has to be directed by its own men and foreign intervention must not exceed the limits of collaboration, otherwise it would be a transculturation that denies the authentic national culture" (Mariategui, 1928). In the same vein, Jorge Basadre indicates that perhaps the essential flaw of the law was that "it implied a top-down order with general theoretical and dogmatic statements, without anyone having to gather its content within reality" (Basadre Grohmann, 1939). This is due to the excessive influence of foreign elements in this legal device, which proposed the reorganization of the educational system without a real knowledge of Peruvian reality.

This law, which was in force for twenty years, was subject to numerous modifications. However, these amendments exacerbated the ineffectiveness of the Peruvian educational system (Marrou Roldán, 2012). In sum, we can say this reform led to a level of dependence and control of the Peruvian Educational system on United States that imprinted the Peruvian society to the point of creating a mismatch between the national project and the reality of Peruvian society. This clearly represented the penetration of American thought in the educational field with negative consequences.

\subsection{Conceptualising policy transfer}

Policy transfer can be defined as a process in which knowledge about policies, administrative arrangements, institutions in one time and place is used in the development of policies, administrative arrangements and institutions in another time and place (as cited in Dolowitz \& Marsh, 1996). This transfer can be 'voluntary or 'coercive' and can involve at least six main categories of actors: elected officials, political parties, bureaucrats/civil servants, pressure groups, policy entrepreneurs/experts, and supra-national institutions (Dolowitz \& Marsh, 1996).

The example above is an instance of policy transfer as a consequence of a narrowed vision of Peruvian society's needs and a strong economic dependence that led the country to play under the rules and conditions of foreign power groups and with the result that it benefited upper classes mostly. The influence of United States in Peruvian public policies could be seen as a case of coercive policy transfers. Over the 
last decades, recurring threats to take foreign investments elsewhere, the imposition of economic policies that were implemented in association with loans by supranational institutions, and the pressure to foster global economic integration, have been typical characteristics of the policy transfers (Dolowitz \& Marsh, 1996) that Peru adopted often with the aim of improving her social welfare.

Therefore a pertinent question addressed here is how the Peruvian government could best respond to the OECD recommendations highlighted in the previous chapter and link those to its national strategic plan. Relevant to this question, Dolowitz and Marsh define five ways to incorporate lessons into a political system: copying, emulation, hybridization, synthesis and inspiration. From all of them, they prefer hybridization and synthesis, as both allow for processes involving the combining of elements of programmes found in two or more countries to develop a policy best-suited to the emulator (Dolowitz \& Marsh, 1996).

For this research, it is also relevant to make a distinction between policy diffusion and policy transfer. Diane Stone (as cited in Rubio Barceló, 2002) states that the term diffusion is often used to define a macro phenomenon, the general process of disseminating a political innovation (e.g., a new approach, a new program, an institutional reform) in several jurisdictions that are part of the same national or international context. The term transfer, on the other hand, is used to denote a phenomenon of a 'meso' nature, the process (or processes) of political decisions that entail the export of a policy, program or approach from one political system to another (Rubio Barceló, 2002). In the case of Peru, it might be interesting to consider both, starting from policy diffusion, as a way to envision the scope and expected results in respect of each policy transfer.

In respect of its capability to effect policy diffusion and policy transfer, the dynamic in Peruvian public sector shares the limitations faced by other countries. Policymakers need more tools to differentiate effective policies that could be extrapolated to their system. In this regard, Dussauge-Laguna notes that the transferred policies are not always the product of a rational process whereby the potential advantages and disadvantages of various options are valued and taken into account in decision making. On the contrary, the transfer processes encounter a set of limitations related to the decisional process itself and to the characteristics of the 
environment in which they were developed, as well as the environment into which they are transferred (Dussauge-Laguna, 2012).

On the other hand, when considering policy transfer, a policy-maker should be aiming to understand the "basic mechanisms" underlying effectiveness, including costeffectiveness, of what a policy has done, assuming, of course, that what they have done is indeed effective and cost-effective (Bardach, 2004). Such an approach would allow identification of the "contingent features" of the observed practice. That is the distinction from those that are merely instrumental or optional, and those that might be adapted in the target site without substantial risk. Therefore, the key in respect of vocational education and training policies for Peru should be that Peruvian policy makers focus on the features that makes a specific system successful, rather than what were the results achieved in a specific context that cannot always be transferred in full.

According to Virginie Mamadouh (as cited in Dussauge-Laguna, 2012), the main purpose of policy transfer and lesson drawing is to bring improvements to the receiving society. Borrowing successful institutions from another jurisdiction is seen as a means to accelerate development or achieve it at lower costs. Borrowing institutions from a successful country is seen as a means to be part of said success (Dussauge-Laguna, 2012). This is basically the main purpose of sharing best practices among countries and is a general consensus not only in Peruvian foreign policy but worldwide. However, a potential problem remains when it comes to the selection of policies/programs that constitute best practices and worthy of being transferred to promote innovations in other jurisdictions. According to Michiel de Vries, cited by Dussauge-Laguna (2012), this has to do with the variable "context". So, the "good / best practice" designation is probably not only because of its intrinsic programmatic characteristics (design, cost, coherence, etc.), but also because it is inserted into an environment that can support it.

International experiences vary too much to know what are the specific characteristics that should be taken as an example to follow when designing specific institutions. In this regard, Dussauge-Laguna refers to the work of Matt Andrews (2010), who analyzes the growing popularity of international indexes of "good governance" and the implications that are extracted from them on what innovations in public 
management should be promoted. The questions that underlie the process, however, are, what best practices are we talking about? How do we know they are such? And, how far will the innovation process also lead to an improvement process?

At the risk of knowing what is or not a "good/best practice", there is therefore a risk of knowing/not knowing if this practice really works and, above all, if it produces the effects that its original promoters/designers argue. Due to the above, it is true that the transfer processes of certain policies/tools of a country can produce interesting government innovations. However it should be taken into account that sometimes such adoption will be accompanied by effects that are difficult to measure/observe, at least in the short term (Dussauge-Laguna, 2012).

The tradition of policy transfer in Peru is to refer to European or United States models. Nowadays, the gaze of Peruvian policy makers is focusing less to the North and more in the East. As mentioned in Chapter 1, Peru's Bicentennial Plan states the importance of strengthening the relationships with the Asia-Pacific region to boost the Peruvian economy. This government policy is likely to again lead Peru to attempt policy transfers or lesson drawing from overseas. Likewise, the program to help Peru to become part of the OECD is already influencing policy makers to adopt recommendations to accomplish the stated milestones. Such motivations are likely to directly influence the future of the Peruvian VET system and can be seen already with the creation of EDUCATEC and the "Proyecta tu Futuro" observatory. However, the objective in this research, informed by policy transfer learning, is on how avoid the "copy-paste policies" and proceed instead through a more organic and contextual policy transfer process, having in mind that the results of these actions might not be exactly as those of the paradigm we are adopting (cited by Dussauge-Laguna, 2012).

Therefore, prior to choosing the policies that we want to transfer to a specific system, in this case, the Peruvian VET system, it might be relevant to better understand the current priorities of the Peruvian Government in terms of the Asia-Pacific region, especially in terms of trade and commerce and the implications these directions might have for the future of VET development in Peru. 


\subsection{Growing influence of the Asia-Pacific Region in Peru}

In the last decades, cooperation among nations has led to closer intergovernmental relations at institutional level and in particular policy areas. Globalization has tended to unify economies, societies and cultures through the enhancement of bilateral and multilateral relationships. This trend is in part a response to the need of domestic and regional economies of diversify their markets and encourage the creation of productive jobs and the innovation of technologies aimed at achieving the highest added value and sophistication of exports. Peru is not outside of this dynamic.

The new economic powers such as China and India are redefining the distribution of power in the international arena, creating an imperative for Peru adopt a new approach to economic development. One in which it leaves behind the assistancebased model where support is demanded from the developed economies (NorthSouth cooperation) and rather one that acquires better opportunities to diversify and transform their productive resources through intergovernmental co-operation, negotiation and trade. In 2010 the National Centre of Strategic Planning (CEPLAN) released the "National Development Strategic Plan" named also "Bicentennial Plan: Peru towards 2021". The strategic strand no. 3 of the Binational Plan, notes that international trade has been moving towards the countries of the Pacific Basin. The boom of economies such as Japan, China, Taiwan, South Korea or Singapore has tended to strengthen integration spaces such as APEC. In this context, Latin America and particularly Peru should be increasingly incorporated into this dynamic.

At multilateral level, Peru's foreign affairs focus is to strengthen ties with the United States and the European Union to become main trading partners and capital investors. At the same time, it is desired to expand ties with Russia, China and the countries of the Asia Pacific region, such as member economies of the Asia Pacific Economic Cooperation Forum (APEC).

According to the Asia-Pacific Economic Cooperation (APEC) reports, growth has soared in this region, with real GDP doubling from approximately just USD 19 trillion in 1989 to USD 43 trillion in 2016, while residents of the Asia-Pacific saw their per capita income rise threefold, lifting millions out of poverty and creating a growing middle class in less than three decades (APEC, 2018). In 1998 Peru became 
a member of APEC. Since then, Peru significantly improved it economic performance. Foreign trade has grown an average of $11 \%$ per year. Exports have grown by $580 \%$, imports have increased by $480 \%$ and investments of member economies in Peru exceed USD 70 billion. Eight of the twenty main business partners of Peru are part of APEC: United States, China, Japan, Chile, Canada, South Korea, Mexico and Chinese Taipei. In terms of exporting, Peru is the main APEC supplier of fishmeal and fish oil, frozen squat and molluscs, asparagus, quinoa, avocado, mango, canned vegetables, grapes, lead, zinc and calcium phosphates, and $80 \%$ of Peru's exports to the APEC economies are in copper, gold and fishmeal. Peru is the only APEC economy that has hosted the APEC Forum twice in a span of eight years (COMEX PERU, 2017).

As a result of the successful outcomes of Peruvian's participation in APEC, the Peruvian government has developed the intention of creating an area of deep integration with its APEC partners to move towards the free circulation of goods, services, capital and people and promote greater growth, development and competitiveness. Consequently, in 2010 the Pacific Alliance was created. The importance of this economic block is the capacity it creates for dealing and negotiating with other major world economies, such as Australia, Canada, New Zealand and Singapore. In order to attract greater investment, Peru is currently negotiating the status of Associated State to the Pacific Alliance. In the beginning of 2018, Peruvian exports to the Pacific Alliance represented USD 360 million, 5.5\% more than in the period from January to February 2017 (Ministerio de Comercio Exterior y Turismo, 2017; Peru Info, 2018).

Informed by observation of this trajectory of the economic importance of the AsiaPacific region in the Peruvian foreign and trade policy, our selection of best VET systems focuses on countries from this region to evaluate a possible policy transfer. 



\section{Chapter 4: Learning from other VET systems}

In this chapter I explain the selection of cases based on indicators and global trends that might influence the performance of each VET system in its respective country. Secondly, I establish six criteria with which to analyse each of the cases selected in contrast with the current Peruvian VET system.

\subsection{Case study selection: global trends and indicators}

The effectiveness of a public policy is linked not only to the construction of a reliable and consistent public system but to external circumstances. Nowadays, there are global phenomena that might affect any governmental policy that countries and even regions are implementing. Therefore, it is pertinent to analyse global trends and indicators to identify the countries of the Asia-Pacific Region with the best performance in a number of indicators such as the Human Capital Index, PISA evaluation, Ease of Doing Business Score and OECD Better Life Index.

\subsubsection{The Global Human Capital Report 2017}

The Global Human Capital Report 2017, developed by the World Economic Forum (WEF), proposes a new benchmark to build the workforces of the future. It provides a means of measuring the quantifiable elements of the world's talent potential so that greater attention can be focused on delivering it. By measuring countries' talent resources holistically according to individuals' ability to acquire, develop and deploy skills throughout their working life rather than simply during the formative years, the WEF hopes to foster a true revolution in educational systems where education is geared to meeting the needs of the future workforce.

The Human Capital Index 2017 ranks 130 countries on how well they are developing their human capital on a scale from 0 (worst) to 100 (best) across four thematic sub-indices: Capacity, Deployment, Development and Know-how, and five distinct age groups or generations: 0-14 years; 15-24 years; 25-54 years; 5564 years; and 65 years and over, in order to capture the full human capital potential profile of a country (World Economic Forum, 2017). 
The results show that the top ten of 2017's edition of the Human Capital Index is headed by smaller European countries-Norway (1), Finland (2), Switzerland (3), Denmark (5) —as well as large economies such as the United States (4) and Germany (6). Four countries from the East Asia and the Pacific region, three countries from the Eastern Europe and Central Asia region and one country from the Middle East and North Africa region are also ranked in the Index top 20. Regarding the Asia-Pacific countries, the United States (4), New Zealand (7), Singapore (11), Canada (14), Russian Federation (16), Japan (17) and Australia (20) are ranked in the top 20 (World Economic Forum, 2017).

\subsubsection{OECD Better Life Index}

The Better Life index aims to measure the well-being of societies by developing 11 topics based on one to three indicators chosen of a number of statistical criteria. These indicators are a measure of the concepts of well-being, in particular in the context of a country comparative exercise. Some of these indicators are income and wealth, jobs and earnings, housing, health status, work and life, education and skills, social connections, civic engagement and governance, environmental quality, personal safety and life satisfaction (OECD, 2019).

Asia-Pacific countries that score highly are: Australia (2), Canada (4), United States (10), New Zealand (12), Japan (25) and Republic of Korea (30). In Education, Asia-Pacific countries are placed as follows: Australia (2), Canada (5), Japan (7), Republic of Korea (11), United States (20) and New Zealand (21).

\subsubsection{Ease of Doing Business Score}

The World Bank has developed the rankings and the Ease of Doing Business Score, in which economies are ranked from 1-190. A high ease of doing business ranking means the regulatory environment is more conducive to the starting and operation of a local firm. The rankings are determined by sorting the aggregate scores on 10 topics, each consisting of several indicators, giving equal weight to each (World Bank, 2019). Asia-Pacific countries score high on this ranking: New Zealand (1), Singapore (2), Hong Kong (4), Republic of Korea (5), United States (8), Taiwan (13), Malaysia (15) and Australia (18) are placed in the top 20. 


\subsubsection{VET in the Asia-Pacific region}

In 2014, the Asia-Pacific Economic Cooperation forum (APEC) developed a project named "Enhancing the Quality and Relevance of Technical and Vocational Education and Training (TVET) for Current and Future Industry Needs-Phase 1". This project was proposed by the Malaysian government, through the Department of Skills Development (DSD) of the Ministry of Human Resources (MOHR), with the aim of assisting Malaysia and 14 other economies to implement one of the priorities of its APEC New Strategy on Structural Reform (ANSSR) Action Plan, which is related to "Upgrading Skills and Capabilities of Existing Workforce to Address the Needs of Industries" (APEC, 2014).

APEC's focus is on policies related to TVET curriculum design based on the analysis of Occupational Frameworks and Occupational Competency Standards. Likewise, it conducts comparative analysis on selected APEC economies, specifically Singapore, Australia and Canada in developing Occupational Analysis (OA) and National Occupational Skills Standards (NOSS) and its relevancy towards industry (Asia-Pacific Economic Cooperation, 2014). Countries in which to conduct a more in-depth review of the TVET system review were selected based on whether there is an established TVET system implemented in their respective economy and the uniqueness of the TVET landscape of each economy. This research reveals that Australia is known for its established and highly industry driven TVET system, Canada for its part, has an established TVET system since the year 1956 and Singapore is among the economies with the highest percentage of skilled labour force with tertiary education (Asia-Pacific Economic Cooperation, 2014).

\subsection{Institutional design of VET: the case of New Zealand, Australia and Canada}

In this section, the selection of three cases of VET systems from member economies of the Asia-Pacific region: New Zealand, Australia and Canada, is explained. These countries were selected based on the indicators mentioned in section 4.1. We will briefly develop each country's profile and approach to VET. 


\subsubsection{Australia}

The total population of Australia stands at 24.8 million, from which $12.62 \%$ are in the age range from 15 to 24 years old. The annual percentage of GDP growth was $2.2 \%$ in 2017 and the main industries are mining, industrial and transportation equipment, food processing, chemicals and steel.

In the Doing Business 2019 rank, Australia takes $8^{\text {th }}$ place among Asia-Pacific countries. In PISA evaluation, it is placed $2^{\text {nd }}$, while in terms of employment rate, it takes $12^{\text {th }}$ position among OECD countries. In the Human Capital Index 2017, Australia is placed in the $20^{\text {th }}$ position of 130 countries ranked.

In terms of foreign affairs, Australia is a recent but important trade partner for Peru. In 2018 both countries signed the Free Trade Agreement, which is the first bilateral agreement that includes chapters on Development; Small and medium businesses; and, Competitiveness and Business Facilitation, achieving in this way an agreement of wide scope and that contributes to the development of the country (Ministerio de Comercio Exterior y Turismo, 2019).

These characteristics give Australia a high relevance for analysis of VET systems in the region. Demographically Australia is similar to Peru in terms of size and both are economies based on mining activity, plus the indicators place Australia in a very good position in terms of economic performance, suggesting that is approaches might be effective in economic development terms

\subsubsection{Canada}

The population of Canada stands at 37.06 million, of which $11.62 \%$ are 15 to 24 years old. The annual percentage of GDP growth was 3\% in 2017 and the main industries are processed and unprocessed minerals, food, wood, paper, fish products, petroleum and natural gas.

In Better Life index, Canada is placed in the $4^{\text {th }}$ position. In PISA evaluation, it is placed in $5^{\text {th }}$, while in terms of employment rate, Canada takes $13^{\text {th }}$ position among OECD countries. In the Human Capital Index 2017, Canada is placed in the $14^{\text {th }}$ position of 130 countries ranked. 
In terms of foreign affairs, Canada is a long-time trade partner for Peru. In 2008 both countries signed a Free Trade Agreement, which turned Canada into the $4^{\text {th }}$ market for export of Peruvian goods. Because the FTA with Canada emphasised the accomplishment of labour standards recognized by the ILO, the international cooperation provided by Canada has focused on strengthening the vocational and technical education in Peru.

For these reasons Canada is a very important and relevant country to be analysed in this research. It is a country demographically similar to Peru in terms of size, a good economic performance and an educational system approaching what could be considered successful in VET education.

\subsubsection{New Zealand}

The population of New Zealand stands at 4.79 million, of which $13.16 \%$ are 15 to 24 years old, $14.1 \%$ are Maori and 7.6\% Pasifika people. The annual percentage of GDP growth was 3\% in 2017 and the main industries are agriculture, forestry, fishing, logs and wood articles, manufacturing, mining, construction, financial services, real estate services and tourism.

In the World Bank's Doing Business 2019 rankings, New Zealand takes the $1^{\text {st }}$ place among all countries. In the Better Life index, it is placed $12^{\text {th }}$. In PISA evaluation, New Zealand is placed $21^{\text {st }}$, while in terms of employment rate, it takes $15^{\text {th }}$ position among OECD countries. In the Human Capital Index 2017, New Zealand is placed in $7^{\text {th }}$ position of the 130 countries ranked.

In terms of foreign affairs, it is projected that New Zealand will become an important partner for Peru in the future. In 2018, New Zealand signed the Comprehensive and Progressive Agreement for Trans-Pacific Partnership (CPTPP), which involves 11 other countries in the Asia-Pacific region. In addition, New Zealand also launched free trade agreement negotiations with the Pacific Alliance to become an associate member. Although demographically there is an important difference in terms of the size of population, for the performance and trade reasons cited above, New Zealand is a key model to be analysed because of its good economic performance, an openness of markets policy and a focus on wellbeing and diversity. 


\section{3 Criteria to analyse VET systems}

In this section we will develop six criteria to select the characteristics of best practices in VET systems based on global trends already mentioned above. These focus on provision, training in workplaces, qualification recognition, provision of information and guidance, improvement of governance, and monitoring and evaluation.

\subsubsection{Provision of VET}

The provision of VET education is one of the most relevant aspects of any system. Nowadays, we can find different provision schemes across the world. One of those is to offer VET education as a series of elective courses taught in secondary school that students can take along with compulsory academic subjects for obtaining a high school diploma. These are usually of an exploratory nature and are designed to give the student a preliminary idea of a particular profession without fully preparing for their employment in that field. A second provision scheme divides the secondary school curricula into academic and technical, which are taught in parallel, either within the same educational unit or in separate establishments. In this scheme, the link between the academic and technical curriculums is limited. Limited also is the link to post-secondary VET, although students are qualified to continue studies at this level. Within this model there are programs that alternate training in schools with training in companies. An institutional variation of the last scheme is to separate the supply of upper secondary education (ISCED level 3) from the previous years. In this way, students must change schools to participate in specialized VET programs, making available the full range of curricular offers in the system. The upper secondary schools maintain links with general education but, in order to favour the educational trajectories of their students, they are connected to tertiary education (Sevilla B. \& Trucco, 2017).

Regarding provision in higher education, there is a distinction between segmented and comprehensive schemes. In segmented schemes, VET programmes are taught in its own institutional environment and in parallel to the university sector, usually with differentiated regulation and financing systems for each. Within these binary schemes, a key difference lies in the systems that promote transfers of graduates 
from the higher VET to the university sector to reach higher grades, and those that do not need to do so because the sector itself offers training alternatives leading to higher degrees equivalent to those taught by universities (undergraduate, masters or doctorate). In comprehensive schemes, VET at tertiary level is taught only in universities in the form of intermediate degrees known as technical degrees. It is also possible to find unified systems where, as a next stage in the process of diversification of higher education that occurs with the emergence of the VET sector, the two sectors move together until they converge into a single generalized system where the boundaries between technical education and the university are diffuse (Sevilla B. \& Trucco, 2017).

In this regard, the OECD recommends that professional education and training needs an institutional base that a) offers short-cycle professional programmes in a tier of institutions separate from universities; b) makes use of the successful model of universities of applied science where relevant; c) consolidates training providers into institutions of adequate size; and d) provides a consistent framework of public funding for professional education and training, avoiding distortions and backed by quality assurance (OECD Reviews of Vocational education and training, 2014).

In New Zealand, VET is offered as an option through senior secondary education, tertiary education courses, and ongoing professional development in the workforce (Industry Training Federation, 2018). Secondary education comprises ages 13-18 (Years 9-13), and at senior or upper-secondary school level students may begin to specialize in vocational learning through access to trade-developed qualifications and specialist trades academies that teach trades and technology programmes to students in years 11-13 (ages 15-18). They are run through schools and often in partnership with other providers. In post-secondary education, the Youth Guarantee programme provide students aged 16-19 with an opportunity to study towards the National Certificate of Educational Achievement (NCEA) Level 1-3 or Level 1-3 at tertiary providers free of charge. These courses can be academically or vocationally focused. Likewise, institutes of technology and polytechnics teach professional and vocational education and training from introductory studies to degrees. (Ministry of Education of New Zealand, 2018). 
The boundaries among institutions and other providers of post-school education and training are not rigidly imposed in New Zealand so TVET can be found in schools and in universities. Students can choose to continue with technical and vocational education and training (TVET), continuing or higher education in a range of learning environments (UNEVOC, 2012).

In Australia, students can undertake VET at school. As a consequence of education being a state responsibility, there tends to be some minor variations in how this is implemented across the states. In Queensland State for instance this might be:

- as part of their school studies, delivered and resourced by a school Registered Training Organisation (RTO). These can include Technical and Further Education (TAFE) institutes and private colleges.

- by enrolling in a qualification with an external RTO, funded either by the Department of Education's VET investment budget or through fee-for-service arrangements i.e. where the student or parent pays for the qualification

- $\quad$ as a school-based apprentice or trainee (Queensland Government, 2018).

VET courses are primarily offered by RTOs. Some universities may also offer VET courses in addition to higher education courses. VET programs in schools, called VET in Schools (VETiS), were also established with the specific aim of enabling students to undertake both nationally accredited VET programs (including part-time apprenticeships and traineeships) alongside programs that enable students to complete their secondary school certificates (Misko, Korbel, \& Blomberg, 2017).

In Canada, VET varies across provinces and territories, sectors, and communities to meet the specific needs of the target populations. Overall, VET in Canada refers to a multi-year programme or series of courses providing specialized instruction in a skill or a trade intended to lead the student directly into a career or programme based on that skill or trade. These programmes may be offered (1) in secondary schools; (2) at the postsecondary level in public colleges and institutes; (3) in private for-profit colleges; and (4) in the workplace, through apprenticeship programmes. Programs usually require one or two years of study, although some 
private career colleges offer programs of shorter duration (Asia-Pacific Economic Cooperation, 2014). During those two-years more optional courses are available to students, when they can choose between different specialized programmes that prepare them either to enter the job market or to enrol in postsecondary colleges, universities or other institutions of their choice (UNEVOC, 2013).

Currently, in Peru there is an oversupply of IES and a high demand of EEST, which indicates that Peruvian students seek to obtain a more specialized technical education focused towards innovation and technology. Therefore, the Government decided to develop a segmented system in which it offers technical education that leads to higher degrees equivalent to those taught by universities. Compared to the systems analysed above, provision of VET in Peru is more rigid and does not facilitate easy progression from polytechnics to university higher education or indeed from school to either of these.

\subsubsection{Training in workplaces}

Training in workplaces might include professional internships, internships, alternation between school and company, and apprentice programs with employment contracts, among others. The promotion of these approaches in VET, together with developing relevant competences that are achieved only in real environments, allow us to improve the relevance of the contents of this education with the requirements of the job positions. The policies oriented towards this area have focused on the assurance of quality of training processes in placement companies through the establishment of regulations and mechanisms for evaluation and certification of learning taking place in these contexts (Sevilla B. $\&$ Trucco, 2017).

Despite its compelling advantages, work-based learning is too often undervalued as part of VET. One reason may be that it conflicts with a common assumption of the education industry - that learning should be fostered by an academically trained teacher in an academic institution and subject to an academic assessment. Instead, work-based learning is usually pursued under the guidance of a supervisor rather than a teacher, in a workplace rather than a classroom, and often subject to a practical assessment of competence rather than an academic test (OECD Reviews of Vocational Education and Training, 2014). 
The New Zealand Apprenticeships programme is an employment-based education initiative aimed at encouraging participation in industry training by young people aged over 16 years old. All trainees enter into a training agreement with their employer, and their progress is assessed by registered assessors. The Industry Training Organisations (ITOs) facilitate individual training arrangements, purchase off-the-job training from tertiary education providers and then tailor these arrangements to the needs of learners and employers. ITOs offer training and qualifications for specific industries (for example, agriculture, building and construction, motor trade). The costs of training are met jointly by government and industry. (Ministry of Education of New Zealand, 2018).

In Australia, apprenticeships are associated with an occupational entry level qualification at Certificate III or IV level and have a duration of 3-4 years. Traineeships are undertaken at Certificate II or III level, have a duration of less than 2 years and generally cover service-oriented occupations. Both combine time at work with off-job training and can be full-time, part-time or school-based. They are available to anyone of working age, do not require any entry qualifications and are available in a variety of certificate levels in over 500 occupations. Employers are responsible for meeting the cost of supervision, providing on-thejob training and verifying that an employee has attained on-job competence. Apprentices and trainees contribute through the opportunity cost of training wages and may have to cover the cost of tools and equipment. In Australia, apprentices and trainees are paid a wage that increases as they progress (Ministry of Education of New Zealand, 2010; UNEVOC, 2018). There is also the Australian Schoolbased Apprenticeship, which is undertaken part-time while the apprentice or trainee is still attending school. It combines paid employment, on or off-the-job vocational training and senior secondary school studies. This provides senior secondary students with hands-on industry experience, and the ability to work towards or complete a nationally recognised qualification, while they complete their senior school certificate (Australian Apprenticeships Centre, 2018).

In Canada, Apprenticeship Programmes last typically four-years. Here the related industry is responsible for practical training delivered in the workplace, and educational institutions provide the theoretical components (UNEVOC, 2013). After completing institutional and work-placed training, apprentices can receive a Certificate of Apprenticeship (for non-restricted trades) or a Certificate of 
Qualification (for restricted trades). Depending on the trade, it takes about two to five years as an apprentice to become a certified journeyperson. Each province and territory has its own training and certification policies and its own list of designated apprenticeship programmes (OECD, 2014a). Also, apprentices can apply for the Apprenticeship Incentive Grant, which is a taxable grant of CAD 1000 per year for registered apprentices who have successfully completed their first and/or second year of an apprenticeship programme, up to a maximum of CAD 2000 per apprentice. The Apprenticeship Completion Grant is a CAD 2000 taxable grant available to registered apprentices who successfully complete their training and obtain a journeyperson certification in a designated Red Seal trade (Cheung, Guillemette, \& Mobasher-Fard, 2012).

The Interprovincial Standards Red Seal Program promotes a set of common standards that allow the recognition of certifications across provincial jurisdictions. Tradespersons who have successfully passed the Red Seal examination receive a Red Seal endorsement that indicates that a tradesperson has demonstrated the knowledge required for the national standard. Through the Red Seal Program, examinations are developed and maintained through a rigorous industry-driven process for 56 Red Seal trades (Red Seal, 2019).

Currently in Peru, the National Curriculum for Basic Education does not establish the necessary conditions to achieve a transition to the world of work. The Ministry of Education has yet to develop a national framework of competencies or professional qualifications that sets higher quality standards for the technical education institutes and teaching aligned with the demands of the labour market and industry. Moreover, despite the move to the recognition of competencies there is no provision for facilitating work place learning while still at school or facilitating progression to technical education and workplace learning while still enrolled at school.

\subsubsection{Qualification quality and recognition}

National qualifications frameworks (NQF) have been positioned as a popular policy to improve the quality and relevance of VET programmes, since they establish a formal framework for the recognition of competence standards in 
different learning domains and procedures for the evaluation and certification of competencies. However, it is noted that qualifications frameworks can only be considered as part of a broader set of policies to ensure quality and consistency in the provision of VET in countries (Sevilla B. \& Trucco, 2017).

Many OECD countries are currently implementing qualifications frameworks, as they can make vocational education and training systems more transparent, so that the value of different qualifications can be more clearly recognised by students, employers and other stakeholders. If frameworks are underpinned by a strong methodology for allocating qualifications to levels and learning outcomes, supported by key stakeholders, and backed by complementary measures to unify the vocational and professional system and improve transitions, they can be a key means to facilitate lifelong learning, and improve access to higher level education (OECD, 2010).

In New Zealand providers offer qualifications registered on the New Zealand Qualifications Framework (NZQF) which is administrated by the New Zealand Qualifications Authority (NZQA). The NZQF is the national definitive source for accurate information about all quality assured qualifications, covering senior secondary school and tertiary education qualifications, and including all qualifications open to international students. The approval of qualifications is developed in two stages. The first one involves approval to develop a qualification. This stage ensures that all new qualifications are relevant and do not duplicate existing qualifications. The second stage occurs once the qualification has been developed and involves approval of the qualification. Moreover, the Tertiary Education Commission (TEC) makes its decisions about what to fund based on both quality and relevance. Quality is judged by the course leading to credit towards a qualification on the framework. Relevance is judged against contribution to the Tertiary Education Strategy (TES) (Tertiary Education Commission, 2018).

In Australia, the Australian Qualifications Framework (AQF) covers qualifications from the tertiary education sector (higher education and vocational education and training) in addition to the school-leaving certificate; the Senior 
Secondary Certificate of Education. The AQF's objectives are to provide a contemporary and flexible framework that:

- Accommodates the diversity of purposes of Australian education and training now and into the future.

- Contributes to national economic performance by supporting contemporary, relevant and nationally consistent qualification outcomes which build confidence in qualifications

- Supports the development and maintenance of pathways which provide access to qualifications and assist people to move easily and readily between different education and training sectors and between those sectors and the labour market

- Supports individuals' lifelong learning goals by providing the basis for individuals to progress through education and training and gain recognition for their prior learning and experiences

- Underpins national regulatory and quality assurance arrangements for education and training

- Supports and enhances the national and international mobility of graduates and workers through increased recognition of the value and comparability of Australian qualifications

- Enables the alignment of the AQF with international qualifications frameworks (Australian Qualifications Framework Council, 2013).

In Canada, the Canadian Degree Qualifications Framework comprises three general degree categories that are intended to capture the most salient aspects of the three principal degree levels offered in Canada. It provides a broad framework for each degree level, leaving to each province/territory the development of more detailed qualifications frameworks for degree credentials offered in its jurisdiction. The federal government works closely with provinces and territories to manage and deliver programmes in the Red Seal Program. While professional certificates or licenses are recognised by all provincial jurisdictions under the Agreement on Internal Trade (AIT), the Red Seal provides the assurance that workers are qualified according to common standards of knowledge and competency as defined by industry (OECD, 2016). 
In the case of Peru, while the National Catalogue of the Educational Offer is an important step for the building of an integrated VET system, the Ministry of Education has yet to develop a National Qualifications Framework. (NQF), as we mentioned before. There is no enough information to analyse the current process of development of NQF IN Peru. Moreover, the National Catalogue of the Educational Offer currently appears to be more of an isolated administrative device than a core piece of integrating institutional architecture of a VET system with mechanisms for recognising the content, levels and outcomes of education programmes in a transparent way.

\subsubsection{Information and guidance}

The OECD recommends underpinning pathways of progression with high-quality career guidance and information before entering and during professional programmes. Good career guidance based on labour market outcomes can help align the mix of provision to the needs of employers: better overall information on labour market prospects in various professions and more weight given to it in student choice also have an impact on institutions (OECD Reviews of Vocational education and training, 2014).

The Economic Commission for Latin America and the Caribbean (ECLAC) also highlighted the importance of vocational guidance. Provision of good quality career information and guidance seeks to empower students to make autonomous and well-informed decisions about their educational and work trajectories. Such provision has potential for addressing the existing evidence about inequity in access to information and decision-making capacity due to cultural and social factors that affect access and permanence in the education system. The recommendations in this area are to implement strategies of individual counselling based on information about the learner's aptitudes and interests, as well as the existing labour and educational alternatives. Sevilla and Trucco (2017) urge countries to build comprehensive guidance systems that have the necessary resources and with the collaboration of business and higher education institutions.

In New Zealand, career information, advice and guidance are explicit in the New Zealand Curriculum, from Year 7. The National Administration Guidelines (NAGs) explicitly require schools to provide a high-quality, school-wide, 
integrated, culturally responsive career development programme (Careers New Zealand, 2016). There are two main parts to careers education and guidance: a) careers education (developing career management competencies of all students); and b) providing guidance (specific to each student's needs). In addition, the benchmarks are a self-review tool for schools focused on student's needs and competencies, and a future-focused, aspirational set of guidelines school that communities can use to evaluate their own career development provision. These benchmarks provide a bridge between NAGs and Career Education and Guidance in New Zealand Schools. The Education Review Office (ERO) recommends that schools use the Career Education Benchmarks to review the quality and effectiveness of their careers education and guidance (Careers New Zealand, 2016; Education Review Office, 2015). The NZQF also provides information about what knowledge and experience holders of qualifications can be expected to have (New Zealand Qualifications Authority, 2018).

In Australia there are several policies related to career guidance that have been implemented by the central government over the last decade. One of them is the Australian Blueprint for Career Development, which enables teachers, parents, career development practitioners, employment service providers, employers or others who are in a position to support people's careers and transitions, to work with a nationally consistent set of career management competencies which will help all Australians to better manage their lives, learning and work (Morgan, 2010). Likewise, Australian government has established career education lighthouse schools, which use a wide variety of career guidance and counselling methods. These methods include students being paired with mentors, workshops, mock interviews, work simulation, the real game method and visits to industry. In addition these schools feature work placement, information sessions, job interviews, and individual counselling (Gysbers, 2008).

Australia has also developed a strong Career Advisers network. They are registered as professionals by the Career Industry Council of Australia and are required to have completed an appropriate career development qualification, adhere to a code of ethical standards and maintain a minimum standard of ongoing learning that ensures that their knowledge and skills are constantly updated to 
ensure accuracy of the advice being provided (Career Industry Council of Australia, 2016).

In Canada the government created the "Canadian Standards and Guidelines for Career Development" with the aim of spelling out the competencies that service providers need in order to deliver comprehensive career services to clients across the lifespan. It helps also to map out the knowledge, skills, and attitudes that practitioners need in order to deliver quality career development services to clients (The Canadian Standards \& Guidelines for Career Development Practitioners, 2019). However, student needs may vary from region to region, and a number of methods are used including counselling, assessment, instruction, information, work experience, consultation, referral, placement, and follow-up. Instruction involves group presentations, lessons infused into the curriculum, classroom life/work simulations, role playing, and peer support groups (Gysbers, 2008).

Canada has also developed the "Blueprint for Life/Work Designs", which is the national learning outcome framework of the competencies (skills, knowledge and attitudes) that citizens of all ages need to improve lifelong to prosper in career and life in the 21 st century. The Blueprint is a companion piece to the Canadian Standards and Guidelines for Career Practitioners for career professionals. The Australian Blueprint for Career Development was modelled on Canada's Blueprint (The National LifeWork Centre, 2019).

Career information and vocational guidance has not been considered in the recent reforms of Peruvian basic education or as an integral part of the Peruvian VET system. Before 2015, there was a Direction of Tutoring and Educational Guidance that issued reports about the status of the vocational education in Peru. Currently, the Ministry of Education runs a tutorial program called "Integral tutorial care" that seeks to meet the needs, interests and expectations of students through training spaces that seek to prevent violence, school dropout and low academic performance. The objective of this service is to develop socio-affective skills for the construction of a life project in three aspects: personal, occupational and community. A methodological approach of "Project-based learning" and "Cooperative learning" is applied, and the vocational education is considered as a part of the life project. Also, the creation of targeted programs such as the web 
platform "Proyecta tu futuro", the "Competencies Committee" or "Superatec" are attempts to fill this gap but perhaps are not as integrated with other initiatives as they could be.

\subsubsection{Improvement of governance and participation of the parties interested}

The commitment of different VET stakeholders varies considerably between countries, in terms of institutional structures that support their participation, as well as in tasks and actions they carry out (consultative or real decision-making). Likewise, their participation can be established at national, regional or institutional level. Overall, different levels of participation benefit the meeting of objectives of VET systems. One obstacle to the involvement of different parties in VET is the marked institutional fragmentation that characterizes the governance in the provision of this type of education at different educational levels (secondary, tertiary and vocational training) (Sevilla B. \& Trucco, 2017).

In many countries the governance of post-secondary professional training involves a number of agencies, reflecting a division of responsibilities between different ministries, the relative autonomy of post-secondary institutions and the separate roles of private training providers, employers and trade unions. Some countries also have strong co-ordination mechanisms through which a body with responsibility for co-ordination can link the different sectors of the system, and engage the social partners, without damaging local innovations. The OECD recommends creating an institutional framework to co-ordinate professional education and training, engaging employers and organised labour, so that programmes and qualifications are comprehensible and accessible to key stakeholders (OECD Reviews of Vocational education and training, 2014). On the other hand, ECLAC recommends constituting VET National Councils as supra-ministerial institutions (Sevilla B. \& Trucco, 2017).

In New Zealand VET system, the Ministry of Education is the main public body in charge of education policy in the country. Delivery is supported by Crown entities such as New Zealand Qualifications Authority (NZQA), Careers New Zealand and the Tertiary Education Commission (TEC) which are monitored by the Ministry of Education and united through the Tertiary Education Strategy. I respect of VET outcomes, TEC is jointly monitored by the Ministry of Business, 
Innovation and Employment, which provides labour market information to help providers and students. Industry Training Organisations are recognised by the Associate Minister of Education (Tertiary Education) under the Industry Training Act 1992. ITOs are established by particular industries and are responsible for setting national skill standards for their industry which go towards qualifications registered on the national Qualifications Framework (New Zealand Productivity Commission, 2017; UNEVOC, 2012).

Australia's VET sector is organized around VET regulators across the country that supervise training providers, known as Registered Training Organisations (RTOs). These regulatory bodies monitor compliance with the VET Quality Framework or the Australian Qualifications Training Framework (AQTF) through audits. The Australian Government Department of Education and Training (national department), State and Territory Governments are responsible for the development of VET policies. At the national level, Australia's VET system is led by a council made up of Australian state and territory government ministers responsible for industry and skills. The Council of Australian Governments (COAG) and the Australian Industry Skills Committee (AISC) provide leadership and direction for the sector. The AISC provides advice to ensure training in each industry meets the needs of that industry's employers. In addition, Service Skills Organizations (SSOs) support Industry Reference Committees (IRCs) to oversee the development of industry Training Packages (UNEVOC, 2018).

In Canada there is no federal Ministry of Education. In each of Canada's thirteen jurisdictions (ten provinces and three territories), ministries of education are responsible for planning, implementing, and evaluating TVET policies through consultation and/or in partnership with the Council of Ministers of Education, Canada (CMEC) another intergovernmental bodies, such as "Employment and Social Development Canada", the "Canadian Education Statistics Council", "Aboriginal Affairs and Northern Development Canada", "Industry Canada", "Association of Universities and Colleges of Canada", the "National Association of Career Colleges", "Colleges and Institutes Canada", "Polytechnics Canada", among others. The range of organizations involved in various jurisdictions 
includes those from the education, health, culture, social services, employment, immigration, and other sectors. (OECD, 2015; UNEVOC, 2013).

In the case of Peru, we noted in chapter 2, a considerable institutional fragmentation, segmentation and overlapping between the three competent ministries. For instance, although the PNDP and the OECD report states the importance of the linkage between CITEs and the academic and entrepreneurial sector, this is not happening in practice. The Ministry of Education could be better connected to the Ministry of Labour, especially regarding the targeted programs that currently are overlapping tasks. There is currently no connection between the Ministry of Labour and the Ministry of Production, especially between the targeted programs and the CITEs.

\subsubsection{Monitoring and evaluation}

The development of effective public policies might be a difficult task, but the successful implementation of these policies is even more critical. Having evidence of the results of policies and practices in VET is beneficial for decisionmaking and to provide feedback to training institutions. Having good data and information about the labour market outcomes of VET programs is crucial to justifying the professional decisions of students and to adjusting the offers of the VET centres and the governmental priorities regarding to funding. In this regard, it is highly important to create specialized research centres in VET that contribute to the development of policies and institutional practice through data collection, optimization of provision, research and analysis (Sevilla B. \& Trucco, 2017).

In New Zealand, the Tertiary Education Commission monitors and supports the performance of the tertiary education organisations (TEOs), in order to make sure they are delivering the programmes outlined in TEO Investment Plans and to review overall TEO performance and financial viability from the point of view of the government as an investor. Likewise, the New Zealand Qualifications Authority (NZQA) monitors individual TEOs' effectiveness in delivering quality education outcomes through the external evaluation and review of qualifications. NZQA's reviews make judgements about a range of issues, including student outcomes and stakeholder perspectives on the TEO's performance in meeting needs. Standard-setting bodies, including ITOs, are responsible for approving, 
moderating and reviewing standards within qualifications and programmes. At the policy level, the Ministry of Education the monitors sector performance as a whole, especially progress towards the achievement of the Tertiary Education Strategy (TES) which is refreshed five-yearly (Ministry of Education of New Zealand, 2011; Tertiary Education Commission, 2019). The Ministry also conducts research into the outcomes of tertiary education policies and publishes these to assist the sector as a whole to understand its current performance against expectations and future needs.

In Australia, the National Centre for Vocational Education Research (NCVER) is an independent, not-for-profit Australian organisation responsible for collecting, managing, analysing and communicating research and statistics on the Australian vocational education and training (VET) sector. One of its main roles is to undertake a strategic program of education and training research, also collects and publish research findings on VET and directly-related research from across the world. NCVER provides a professional research, analysis and evaluation capability across Australia and internationally (National Centre for Vocational Education Research, 2019).

In Canada there is no single agency or institution responsible for evaluation and assessment of the education system as a whole. However, assessment is a key component of each provincial and territorial education system and a key area of collaboration through the Council of Ministers of Education, Canada (CMEC). CMEC is involved in the design, implementation, and analysis of both panCanadian and international assessment programs, as well as other large-scale studies to examine educational environments and their outcomes. There is also a Framework for Statistics on Learning and Education in Canada (2010), aligned with the Learn Canada 2020 framework, which was introduced to enable a strategic approach to data collection for monitoring, evaluation, and accountability in a decentralised education system (OECD, 2015).

In Peru, EDUCATEC is meant to monitor and evaluate the creation and management of EES. Currently it is focusing its work in licensing EESP and IES as a first step, however, it is an incipient work that needs to be complemented by other actions, as we will analyse in the next chapter. 


\section{Chapter 5: A proposal to construct an effective VET system in Peru}

In this chapter I return to the characteristics of the Peruvian VET and the context in which it operates, to discuss what are the sound policies that Peru can maintain, and which should be changed or improved to optimize the VET system. I suggest a linked set of proposals that consists of development in upper secondary school, workplace training and career information and guidance to reduce fragmentation and improve the performance of VET to meet the needs of SMEs and the economy. It is important to highlight that these proposals are made from the perspective of institutional design and improved governance of VET outcomes and do no focus on factors associated with pedagogical improvement which needs to be the focus of another study.

\subsection{Panorama of the Peruvian social context}

Over the last 10 years Peru has reduced its rate of monetary poverty by almost half. In 2018 the monetary poverty rate was 20.1\%, which is still a high rate compared with OECD countries. But overall, the country has shown the ability to save and invest a large part of the domestic product and generate a high growth rate. This has included, for example, a record of growth in agriculture, a developed infrastructure, administrative and financial systems capable of collecting taxes and mobilizing savings. The Peruvian development model is, in sum, neoliberal, however, its success in any given situation depends on its ability to build strong governmental institutions (Hunt, 2011).

In this regard, Peruvian government and its institutions can be considered weak, particularly in public management institutional design, high levels of fragmentation and corruption. This context increases the difficulties faced in implementing reforms in any field, but it is especially difficult for the educational sector, which is highly affected by any external influences. This vulnerability was particularly visible during the earthquake events in 2007, the national strike of teachers against the public teaching career reforms, the flooding caused by "E1 Niño" phenomenon in 2017 and just recently, the big national debate about the implementation of the gender approach in the educational curricula, which is confronting liberal and conservative sectors of civil society and political parties. 
In all these events the influence of the Ministry of Education was very limited, which affects the regular course of other urgent policies to be implemented.

Despite this situation, there are positive policies that the Peruvian government has implemented to improve the VET system that should be further developed in the future. These include the creation of EDUCATEC as a regulatory institution, the approach of the National Curriculum of Basic Education (NCBE) regarding technical skills and entrepreneurship and the intention of the government to create a National Qualification Framework. On the other hand, even though CITEs network has not been fully implemented, it can still play a key role in the construction of a VET system. All these features can play a key role in the construction of a more efficient VET system.

\subsection{Improving the governance of VET education in Peru}

Having in mind the characteristics of the Peruvian socio-political context, I developed a proposal oriented towards the improvement of the governance in VET (fig. 3). The first change in the governance system should be to connect all institutions that play an important role in VET education, but mainly the Ministry of Education, the Ministry of Labour and Employment Promotion and the Ministry of Production.

If we observe the current system (fig. 1) we will realise that ministries are not well connected. In fact, there are only two ministries that are working together on targeted programs (Education and Labour), while the Ministry of Production is running alone within the system. In Peru, the Executive branch is articulated by the Presidency of the Council of Ministers (PCM). PCM coordinates and monitors policies and programs of a multisector nature of the Executive Branch, with the aim of matching priorities and ensure the compliance with national interest objectives. Thus, PCM should lead the linkage between these three ministries to optimize the functioning of the VET system.

The second step should be to create a comprehensive and strong career information and guidance service that can be directly connected to schools and productive sector. As we mentioned in chapter 4 , the targeted programs that have 
been launched over the last years should be integrated in one single system. Currently, "Proyecta tu futuro" and "Ponteencarrera.pe" are good initiatives, but unfortunately, they are overlapping information and are not properly advertised among students and parents at secondary level. The Ministry of Labour plays a key role in this case, as it should work closely to the Ministry of Education on the improvement of this system. The first one should use the database of both programs to inform about the current labour market, whereas the second should diffuse the information among students, as well as provide them of counselling and career guidance based on labour market outcomes and each student's needs.

Such system would require more budgeting for each ministry. As we analysed before, guidance systems in Australia, New Zealand and Canada are strongly interconnected with their educational system in each country. In the case of Peru, this system might be supported through public-private partnerships initially, and in a second stage, by the government. Currently there are some initiatives from private EEST to inform secondary students about the advantages of following a technical career. Moreover, at present "IPAE Accion Empresarial", a private institution, is supporting "Ponteencarrera.pe", so we can say this system could be feasible, having in mind the Peruvian social context's features.

The career information and guidance system should also be connected to CITE network. This network comprised by 46 centres divided by geographical region, type of administration and productive sectors are aimed to contribute to improvement of productivity and competitiveness of SMEs. As OECD states, CITEs should work with a variety of EEST to help SMEs to meet their objectives in terms of improving its human capital. The career information and guidance system can provide CITEs of information about capacities of students and CITEs can inform to this system about the needs of the labour market. Both combined can develop a database that would also be helpful to the other parts of the VET system.

The CITE network could also be connected to the workplace training system, in the same way as ITOs in New Zealand and RTOs in Australia. CITE network could potentially play the role of facilitating individual training arrangements for 
each productive sector, according to the labour market needs and promoting innovation and technology transfer at the same time.

The most serious limitation about the creation of the career information and guidance system is the shortage of counsellors and advisors across the country. It is being reported the shortage of psychologist and social workers per each school. Thus, at present there is no institutional basis in which this system could build its foundations. The involvement of the private sector might be a solution; however, this also represent a risk since counsellors might report skewed information only to meet the needs of private institutions for increasing the number of enrolments.

\subsubsection{Implementation of reforms in the Peruvian VET system: the case of CITEs network}

In 2016, the United Nations Industrial Development Organization (UNIDO) released a report named "Gaps and development opportunities for Productive Innovation and Technological Transfer Centres (CITE) in Peru. Independent analysis of CITE Wood Lima, CITE Leather and Footwear Lima and CITE Agribusiness Ica". After two years of the implementation of the PNDP, UNIDO concluded that the massive extension of the CITE network constitutes a great challenge for its operation and administration (Organización de las Naciones Unidas para el Desarrollo Industrial, 2016). The biggest concern of UNIDO about the running of CITEs is the assurance of human, operational and financial resources, strategic plans with breadth to the sectoral value chain, and innovation programs appropriate to the innovation requirements for each of the sectors.

Currently, just four of the 46 CITEs are fully implemented, which is why for realisation of their potential contribution to Peruvian VET, it will be necessary to provide large financial resources from different sources of the state not only to invest in the construction, adaptation and correct operation of the infrastructure of centres, workshops or laboratories, but also in human capital required to carry out these projects. The amount of investment required will be based on the scope of the objectives that Peru want to reach as a country and its comparison with other countries in the Latin American region, such as the Pacific Alliance bloc, Argentina, Brazil or at a world level, such as the OECD 
states members (Organización de las Naciones Unidas para el Desarrollo Industrial, 2016).

Likewise, the UNIDO pointed out that Peru should seek to strengthen the triple helix of innovation University - Business - State, exercising an interinstitutional role by coordinating between the various public and private institutions that work for the increase of innovation in Peru and in which each actor exercises its best know-how. For this, the CITE must play an articulating and management role (Organización de las Naciones Unidas para el Desarrollo Industrial, 2016).

After the release of this report, the focus of the Ministry of Production and the Executive Power changed drastically, leaving in stand-by the implementation of the PNDP and further initiatives until a better approach of the hole project. The former Minister of Production Pedro Olaechea stated, regarding the CITEs project, that "it was necessary to analyse if our productive bases are in accordance with the basic levels of competitiveness. And then, just, start to build" (Olaechea, 2018).

Situations like this are very common in Peruvian public sector. There is a pressure to the public administration from political and civil society groups to show up visible outcomes. This pressure leads to ministries to implement programs with massive budget and big expectations but poor results in the long run. In addition, high levels of bureaucracy, corruption of public officials and political instability that affects all public institutions cause that any reform will take more time to be fully implemented. In such complex society affected by multiple factors it is very important to evaluate the effectivity of each mechanism of reform and observe its outcome. This must be done not only to apply policy transfers but to implement any reform. For this reason, the proposals presented in this research is meant to be gradually implemented, first through pilot programs in urban areas and industrialized regions such as Lima, La Libertad, Arequipa and Cuzco. Subsequently, across the country. 


\subsection{Provision of VET service in Peru}

In chapter 2 we analysed the context in which the Peruvian VET is provided. A picture appeared of an institutional framework still under construction. First of all, the two main VET institutions, EEST and IES, are not meeting the demand for technicians that the labour market is requiring, especially those of the SMEs. Moreover, there is a big proportion of students that are enrolled in private EEST, which means that the economic burden of having an education is shouldered by students and their families. Historically Peruvian governments have neglected indigenous population, causing high levels of structural poverty. Having in mind the potential for VET to provide labour market access in needed area of the economy, and that for the most part the students in VET institutions come from poor household (Sevilla B. \& Trucco, 2017), barriers to participation in this sector are problematic for development. It is very demanding for learners from poor households to pay enrolment fees, not only because of the affordability issue. Fees can cause a big rate of abandonment in the long run, and because none of these institutions have been monitoring properly on the last decades, the education outcomes remain uncertain. Thus, students might be paying for a VET service that is not going to be pertinent or useful after they graduate and lacks the expected quality. Therefore, a first measure should be to reduce costs of fees to students and families through the provision of a quality public VET education.

The past decisions of Peruvian governments that have resulted in a segmented system have occurred in part as a response to the quality requirements of the labour market. That is to say, according technical education the same status that university education by awarding the same degree (i.e. Bachelor in technical studies, etc.) has been used as a means of valuing VET. With this measure the government expects to enhance the reputation of Peruvian VET by improving the quality of the service, for instance, through the development of research projects as a requirement or the performance of traineeships or apprenticeships to award the degree. The OECD emphasises the importance of creating universities of applied science as a best practice that worked out in countries like Republic of Korea, for instance. In Peru, the problem with adopting this approach comes from the socioeconomic situation of students, who might need to extend the amount of 
time spent in academic institutions without receiving any payment for about 4 years. Having this in mind, I propose a new scheme of VET in the Peruvian educational system (fig.4).

The first change that we can appreciate is that Vocational courses start in Upper Secondary Education. In countries like Australia, Canada and New Zealand, there is a high penetration of VET careers into secondary schools. These countries have been applying a comprehensive scheme in VET and maintained the upper secondary VET, which is a very effective way of developing capacities in students that might need to start working after they graduate from secondary school. And for those that are interested in following post-secondary studies, it is very useful in this situation for them to define their interests and be more prepared for what the labour market needs. In the same line, investing time in short-term courses is preferable to investing in a whole career and expecting to acquire all necessary knowledge. Endless technological changes and labour market demand impulse employers to be constantly update skills and capacities of their employees, thus creating a need for a more lifelong approach to learning and skills acquisition. Given the high relevance of boosting human capital to meet the demand of SMEs, it is important that the government provides public funding for VET. This topic is developed further later.

\subsubsection{Institutional VET vs. workplace VET}

The second potential we can see for Peru is the implementation of workplace training in the VET scheme. Since the creation of EDUCATEC, IES and public EEST are required to facilitate a number of traineeship hours for students to award their degree. Yet the only legal initiatives from the Parliament was trying to compel student to work without any payment for a 3 years period. This is likely to be a barrier to students from poor communities and homes being able to pursue such placements and therefore complete their degrees.

Training in workplaces has become a very good strategy to prepare students for the labour market and to meet the needs of employers at the same time. In the case of New Zealand, Australia and Canada, workplaces provide the opportunity of industry training to students. In Australia, employers are responsible for meeting the cost of supervision, providing on-the-job training 
and verifying that an employee has attained on-job competence, while apprentices and trainees earn training wages (less the minimum salary) and may have to cover the cost of tools and equipment. In New Zealand, the training is offered for specific industries and there is also a co-payment system between the government and industry.

It is very likely that a workplace training scheme, as an integral part of the Peruvian VET system could have a positive outcome. A co-payment between the Government, the industry and students could be part of the ideal scenario. The Government through the Ministry of Labour might oversee the supervision of on-job competences and enforcement of labour rights. The Ministry of Education, through EDUCATEC, might oversee the attainment of competences and the Ministry of Production, and through CITEs it might contribute to prioritize the industries and regions in which workplace training is more pertinent and urgent, as well as monitoring the outcomes of SMEs and the end of the process to subsequently give feedback to improve and update further apprenticeships programs.

One of the limitations of expanding workplace training might be the difficulty of spreading the program across the country from the very beginning, due to budgetary and logistics reasons. In this scenario, it might be effective to follow the recommendations of the OECD about launching a system of grants and recognitions to help high talented students from poor households to pursue their training. A second solution might be to create a pointing system in which students are evaluated in a case by case basis to opt into an apprenticeship program. Finally, workplace training as a policy should be implemented gradually and joined by permanent assessment about its actual effectiveness.

It is important to notice that workplace training, due to its various advantages, might crowd out institutional training in the long run. The discussion about if formal education can provide all the skills and capacities to students to face real world is very complex. Nevertheless, the implementation of the National Curriculum of Basic Education (NCBE) lends weight to the contention that managing projects of economic entrepreneurship is a competence that students should develop during basic education. This being the case, the NCBE projects 
that at least a proportion of graduate students should be able to run SMEs or being part of them effectively. This suggests a complementary role between formal education and workplace training that in a middle or long term is to strengthen SMEs. Again, the importance of developing upper secondary VET is key for the improvement of the educational system.

\subsubsection{The transferability from non-university to university education}

Another key policy should be to improve connections and transferability from VET institutions to universities. As mentioned in chapter 4, the current system is rigid and does not facilitate the progression from IES and EEST to university higher education. As an important enabler of transferability, it is crucial that the government finalises the construction and operationalisation of the National Qualification Framework with mechanisms for the recognition of new qualifications and audit of existing ones. A well-founded NQF will allow students to have a certification of their competences, starting from secondary education, and will facilitate learner pathways and transitions through the whole VET system. For instance, if a student chooses a vocational course in secondary school, this could be considered as a competence in the future and it can serve to validate credits in post-secondary institutions.

In the case of IES and EEST, the goal should be for the transition to be natural and allow students to validate their courses. Currently private EEST have worked better in this regard, but the transition is possible only in some careers and with specific private universities. Students who want to validate their studies outside the private sector circuit do not have the tools and means to successfully do so. The Canadian model is very interesting in this aspect because of its complexity for working on different levels, leaving room to each province for the development of more detailed qualifications frameworks for degree credentials offered in its jurisdiction. This is something that should be considered in Peru, as the diversity of ethnic groups and geography might require to build specific types of competences depending on the context of the available student cohort and regional economic development. 


\subsubsection{Monitoring and strategic planning}

In the construction of an improved approach to VET in Peru, it will be necessary to relocate and realign current institutions and to create new ones. This aspect is particularly important in a context where the only institution that currently plays the role of monitoring technical education is EDUCATEC. As we mentioned previously, EDUCATEC is currently focusing its work on creating quality standards to improve the quality of IES and EEST. In the proposed system we will need new institutions to support and assess the accomplishments of institutional objectives.

On this regard, the Ministry of Education should start to oversee workplace training and a future Career information and guidance system, together with the Ministry of Labour. The Ministry of Production should also oversee workplace training through CITEs, focusing on deliver opportunities to students to participate on apprenticeships or traineeships on the productive sectors that need it the most. The Ministry of Labour and Employment Promotion should oversee the Career information and Guidance system by merge its current targeted programs such as "Proyecta tu futuro" and fully manage Superatec and "Ponteencarrera.pe". This last one is particularly important because gathers data from the electronic payroll of companies, which might constitute the foundation of a wider database.

The Ministry of Labour should also monitor workplace training. SUNAFIL is a specialized technical body, part of the Ministry and responsible for promoting, supervising and monitoring compliance with the socio-labour and occupational health and safety regulations. SUNAFIL is the ideal body to monitor that workplace training is meeting the labour requirements and protecting labour rights of apprentices and trainees. 


\section{Chapter 6: Conclusions and limitations}

\subsection{Conclusions}

The aim of this research was to select and analyse policies that could serve to build a Peruvian VET system and boost SMEs performance. The first step was to picture the current VET arrangements in Peru. Subsequently, I reviewed policy transfer theory to set up the foundations for a comparison between some selected cases of other countries' VET policies of relevance to Peru. After analysing the performance of countries in the Asia Pacific region on a range of economic and social indicators, I selected Australia, Canada and New Zealand as case studies and then developed criteria to draw policies from those cases that could be implemented to create a Peruvian VET system. Finally, I developed a proposal to improve the effectiveness of VET outcomes in Peru.

The criteria developed to compare policies from selected cases were provision, training in workplaces, qualification quality and recognition, information and guidance, improvement of governance and monitoring and evaluation. These key features helped to highlight the current shortcomings of VET system in Peru. They also acted as a reference frame around which the possible reforms could be envisaged and implemented.

My initial analysis concluded that, in terms of governance, the current Peruvian VET system is fragmented, and its components are siloed. Ministries, departments and targeted programmes are essentially disconnected, and overlapping in their efforts. At present, only one targeted programme is overseen by both the Ministry of Education and the Ministry of Labour and Employment Promotion. Neither the CITEs network nor any other targeted programme is as yet an integrated part of a VET system. However, there are some newer governmental initiatives that could act as a foundation from which to build an effective VET system in Peru. EDUCATEC as a regulatory institution represents a key component to guarantee the quality of VET provision. The National Curriculum of Basic Education includes entrepreneurship as a competency, which is very important to set up the foundations of technical education at postsecondary level. Finally, the government is currently developing the National Qualification Framework, which will become 
an important step for recognizing skills at different educational levels irrespective of where the skills were learned.

Having in mind these findings, the main proposal of this research is to build a joined-up governance of VET through improving the linkages between the Ministry of Education, Ministry of Labour and Ministry of Production. At this point we highlight the importance of the Presidency of the Council of Ministers as having a potential to lead the joint collaboration of all parties involved in the reform, as well as and monitoring its outcomes at a higher level. This reform would require some relocation of current institutions and the implementation of new departments and responsibilities.

In this regard, a necessary policy to be implemented is the creation of a career information and guidance service for secondary schools. This service should be connected to the productive sector in order to feedback the information obtained from students and the labour market, specifically SMEs. This service also would gather in one place or system all targeted programmes that are currently providing information, such as "Proyecta tu futuro" and "Ponte en Carrera".

The second proposal of this research is to enhance provision of VET service in Peru. The provision needs to take into account the reality of Peruvian students. By improving the quality of public IES and EEST, students might gain access to a better education without paying more fees. This improvement must be focused first on the opening of upper secondary VET courses that provide an induction to students before following postsecondary education. Secondly, the provision of postsecondary VET should be comprehensive, that is to say, allowing students to validate and accredit their skills both through workplace learning and formal education in institutions. Finally, the provision of VET education should include workplace training as a way of developing the skills and capacities that SMEs need the most, as well as helping students from poor households to receive a payment for their services and prepare them for the labour market at the same time.

These reforms might need to be implemented progressively, due to the Peruvian socio-economic context and after other experiences such as the construction of the 
CITEs network. To guide such a staged approach, learning from New Zealand and the Tertiary Education Strategy, it would be important to develop a strategy to envisage an inclusive VET system that recognises the diverse needs of indigenous and other vulnerable populations and develops appropriate institutions, policies and mechanisms for meeting those.

\subsection{Limitations and next steps}

This research aimed to identify aspects of VET systems in some geographically chosen cases suitable for transfer to the Peruvian VET context and capable of improving the capability of the system to serve the needs of SMEs. The approach to realist evaluation method allowed me to identify the characteristics of each VET system. However, the full method could not be completed due to time and resources limitations. That is to say, the realist review approach was applied to define the selection of best cases according to the needs of the Peruvian context, yet each selected case has not been through a measurement of its successful or not successful performance or mechanisms within a particular context. Another factor was the impossibility of establishing a formal communication with the current policy-makers in Peru. This was particularly complicated during the period of conducting this research during which the government was trying to conciliate with different political groups on the implementation of new educational curricula. Nevertheless, the proposal resulting from this research could be used as a guide to understanding shortcomings and paradoxes affecting current VET policies.

The analysis did not consider some countries from the Asia-Pacific region with a strong economic performance, such as Korea, Singapore or Japan, basically due to the language limitations. After an extensive preliminary literature review which included these countries, the information obtained in English language was not enough to analyse each case properly for the purposes of this research.

The analysis is largely institutionally, and policy focused. There was no attempt to focus on the role of pedagogical practices for improving VET outcomes as this 
was outside the research scope. Further, I did not consider either a cross-sectional approach, for instance, gender or cultural approaches, to improve the transfer of reviewed policies. Regarding intercultural education, Peru is a challenging society. $60 \%$ of people are mixed Amerindian and other ethnicities and $26 \%$ of people are Quechua, Aymara and indigenous of the Amazon. VET education should have an intercultural approach if we want to the system to be effective.

Taking into consideration the complexity of the Peruvian context, it will be necessary for future studies to complete a rapid realist review on each case presented. This would give us an idea of the effectiveness of each system within its same context, under the criteria proposed. Subsequently, a policy transfer could be applied after having in mind a clearer picture of the outcomes. 


\section{References}

Aguerrondo, I. (2009). Conocimiento complejo y competencias educativas (Complex knowledge and educational skills). Ginebra: UNESCO Oficina Internacional de Educación.

ANSSR: Enhancing the Quality and Relevance of Technical and Vocational Education and Training (TVET) for Current and Future Industry Needs-Phase 1, (Economic Committee (EC) 2014).

APEC. (2018). APEC. Outcomes and Outlooks 2017 - 2018. Retrieved from file:///E:/EESTis/Bibliography/Outcomes\%20\%20Outlook\%2020172018.pdf

Aramburú, C., \& Mendoza, W. (2015). El futuro de la población peruana: problemas y oportunidades(The future of Peruvian population: problems and opportunites). Debates en Sociología, 41.

Australian Apprenticeships Centre. (2018). Australian School-basedApprenticeships. Retrieved from https://www.australianapprenticeships.gov.au/australianschool-based-apprenticeships

Australian Qualifications Framework Council. (2013). Australian Qualifications Framework. In A. Q. F. Council (Ed.). South Australia.

Bardach, E. (2004). The Extrapolation Problem: How Can We Learn from the Experience of Others? Journal of Policy Analysis and Management, 23, 205220. Retrieved from https://www.jstor.org/stable/3326147.

Basadre Grohmann, J. (1939). Historia de la República del Perú (1822-1933) (History of the Republic of Peru 1822-1933) (Vol. 16). Lima: Orbis Venture S.A.C.

Career Industry Council of Australia. (2016). National Peak Body welcomes the announcement of a new national career education strategy [Press release]. Retrieved from https://cica.org.au/wp-content/uploads/NATIONAL-PEAKBODY-WELCOMES-THE-ANNOUNCEMENT-OF-A-NEW-CAREEREDUCATION-STRATEGY-1-1.pdf

Careers New Zealand. (2016). Secondary Career Development Benchmarks. Retrieved from https://www.careers.govt.nz/assets/Benchmarks/CareerDevelopment-Benchmarks-Secondary.pdf

Centro Nacional de Planeamiento Estratégico. (2011). Plan Bicentenario: El Perú hacia el 2021(Bicentennial Plan: Peru towards 2021). Lima: Centro Nacional de Planeamiento Estratégico

Cheung, C., Guillemette, Y., \& Mobasher-Fard, S. (2012). Tertiary Education: Developing Skills for Innovation and Long-Term Growth in Canada. Retrieved from Paris: https://www-oecd-ilibraryorg.helicon.vuw.ac.nz/docserver/5k92pghq4247en.pdf?expires $=1543290174 \& \mathrm{id}=\mathrm{id} \& \mathrm{accname}=$ guest\&checksum $=\mathrm{B} 2 \mathrm{FAB} 02$ CB1C5F6D2961DF76089522CC7

Choy-Zevallos, E. E. (2010). Competitividad de las Micro y Pequeñas Empresas (MYPES) ante el Tratado de Libre Comercio (TLC) (Competitiveness of Micro and Small Enterprises (MSEs) before the Free Trade Agreement). Revista de la Facultad de Ciencias Contables de la Universidad Nacional Mayor de San Marcos, 17, 6.

COMEX PERU. (2017). 20 años del Perú en APEC. La historia no contada. (20 years of Peru in APEC. The untold story). Retrieved from https://www.comexperu.org.pe/upload/articles/publicaciones/libro apec/apec 20.pdf 
Comisión económica para América Latina y el Caribe y Organización Internacional del Trabajo. (2013). Progress and challenges in measuring decent work. Work situation in Latin America and the Caribbean).. Retrieved from Santiago de Chile: https://www.ilo.org/wcmsp5/groups/public/---americas/--ro-lima/documents/publication/wcms 213795.pdf

De Jouvenel, H. (2015) Un nuevo orden mundial por construir (A new world order to build). Interviewer: A. d. l. mundializaciones. Le Monde Diplomatique.

Diario Gestión. (2016). Crean comités para promover empleabilidad en turismo, construcción y saneamiento (Creation of committees to promote employability in tourism, construction and sanitation). Gestión. Retrieved from https://gestion.pe/economia/crean-comites-promover-empleabilidadturismo-construccion-saneamiento-113891

Diario Gestión. (2018). Tecsup: Solo 17\% de colegiales optan por seguir carreras técnicas e ingeniería (Tecsup: Only 17\% school students choose to pursue technical and engineering careers). Diario Gestión. Retrieved from https://gestion.pe/economia/management-empleo/tecsup-17-colegiales-optanseguir-carreras-tecnicas-e-ingenieria-234306

Diaz-Barriga, A. (2005). El enfoque de competencias en la educación. ¿ Una alternativa o un disfraz de cambio? (The competencies approach in education. An alternative or new costume?). Perfiles Educativos, XXVII.

Dolowitz, D., \& Marsh, D. (1996). Who learns what from whom: a review of the policy transfer literature. Political Studies, XLIV, 343-357.

Dussauge-Laguna, M. (2012). La transferencia de políticas como fuente de innovación gubernamental: promesas y riesgos. (Policy transfer as a source of government innovation: promises and risks). Estado, Gobierno, Gestión pública. Revista Chilena de Administración Pública, 19, 51-79.

Education Review Office. (2015). Careers education and guidance: good practice. Retrieved from https://www.ero.govt.nz/assets/Uploads/ERO-CareersEduGuid-2015-WEB2.pdf

European Centre for the Development of Vocational Training (CEDEFOP). (2014). Terminology of European education and training policy. Retrieved from: https://www.cedefop.europa.eu/files/4117_en.pdf

European Union Commission. (2016). Education and training glossary. Retrieved from: https://eur-lex.europa.eu/summary/glossary/training.html

Fernández-Villares, J. (2013). El mercado de las TIC en Perú. (The ICT market in Peru). Retrieved from https://portal.mtc.gob.pe/comunicaciones/tic/documentos/mercadodelasticper u.pdf

Guadalupe, C., Leon, J., Rodriguez, J., \& Vargas, S. (2017). Estado de la educación en el Perú. Análisis y perspectivas de la educación básica (State of education in Peru. Analysis and perspectives of basic education.). Lima: Grupo de Analisis para el Desarrollo (GRADE).

Gysbers, N. (2008). Career Guidance and Counselling in Primary and Seconday Educational Settings. In J. A. Athanasou \& R. V. Esbroeck (Eds.), International Handbook of Career Guidance: Springer. Retrieved from https://link-springer-com.helicon.vuw.ac.nz/content/pdf/10.1007\%2F978-14020-6230-8.pdf.

Harwood, A., \& Konidaris, T. (2015). SME Exchanges in Emerging Market Economies. A Stocktaking of Development Practices. Policy Research Working Paper. 
Hunt, S. (2011). La formación de la economía peruana. Distribución y crecimiento en la historia del Perúy América Latina (The creation of the Peruvian economy. Distribution and growth in the history of Peru and Latin America) (Vol. 13). Lima: BCRP; IEP; PUCP.

Industry Training Federation. (2018). Vocational Education. Retrieved from https://www.itf.org.nz/industry-training

Reglamento de Organización y Funciones del Instituto Tecnológico de la Producción (Regulation of Organization and Functions of the Technological Institute of Production ). Decreto Supremo No 005-2016-PRODUCE C.F.R. (2016).

International Labour Organization (ILO). (2006). Glossary of Key Terms on Learning and Training for Work.

International Monetary Fund. (2014). Regional Economic Outlook. Western Hemisphere. Retrieved from Washington D.C.: https://www.imf.org/en/Publications/REO/WH/Issues/2018/05/09/wreo0518

Keep, E. J., Susan. (2012). A Bermuda triangl e of policy? ' Bad jobs', skills policy and incentives to learn at the bottom end of the labour market. Journal of Education Policy, 27, 21. doi:https://doi.org/10.1080/02680939.2011.595510

Klarén, P. (2004). Nación y Sociedad en la Historia del Perú (Nation and Society in the History of Peru). Lima: IEP.

La República. (2016). Estudios en institutos técnicos podrán ser convalidados en universidades desde el 2017 (Studies in technical institutes may be validated in universities since 2017). La República. Retrieved from https://larepublica.pe/sociedad/946417-estudios-en-institutos-tecnicospodran-ser-convalidados-en-universidades-desde-el-2017

Ley de Institutos y Escuelas de Educación Superior y de la Carrera Pública de sus Docentes. Ley No 30512., (2016b).

Linares-García, I. D. R. (2015). Situación de la Educación superior tecnológica y técnico productiva. Hacia una política de calidad (Status of higher technological and productive technical education. Towards a quality policy) (pp. 50). Retrieved from http://www.academia.edu/14695240/SITUACION_DE_LA_EDUCACION_ SUPERIOR_TECNOLOGICA_Y_TECNICO_PRODUCTIVA_HACIA_UN A_POLITICA_DE_CALIDAD

Mariategui, J. C. (1928). Los siete ensayos de interpretación de la realidad peruana (Seven Interpretive Essays on Peruvian Reality). Retrieved from http://www.lahaine.org/amauta/b2-img/Mariategui\%20Siete\%20Ensayos.pdf

Marrou Roldán, A. (2012). Historia de la Educación Peruana y Latinoamericana (History of Peruvian and Latin American Education). Lima: Editorial San Marcos.

McCarthy, M. A., \& Musset, P. (2016). A Skills beyond School. Review of Peru. Retrieved from Paris: https://www.oecd.org/countries/peru/a-skills-beyondschool-review-of-peru-9789264265400-en.htm

Ministerio de Comercio Exterior y Turismo. (2017). Acuerdos Comerciales del Perú. Alianza del Pacífico (Trade Agreements of Peru. Pacific Alliance). Retrieved from

http://www.acuerdoscomerciales.gob.pe/index.php?option=com_content\&vie $\underline{\mathrm{w}=\text { categ ory \&layout }=\text { blog } \& \mathrm{id}=166 \& \text { Itemid }=185}$

Ministerio de Comercio Exterior y Turismo. (2019). Acuerdo de Libre Comercio Perú-Australia (Peru-Australia Free Trade Agreement). Retrieved from 
http://www.acuerdoscomerciales.gob.pe/index.php?option=com_content\&vie $\underline{\mathrm{w}}=$ category \&id $=202 \&$ layout $=$ blog $\&$ Itemid $=240$

Ministerio de Educación. (2016a). Educación básica regular. Programa curricular de Educación Secundaria (Regular basic education. Secondary Education curriculum). Lima: Ministerio de Educación

Ministry of Education of New Zealand. (2010). Industry training systems in other jurisdictions. Retrieved from

https://www.education.govt.nz/assets/Documents/Ministry/consultations/Revi ew-of-industry-training/InternationalComparisons.pdf

Ministry of Education of New Zealand. (2011). Industry training review. Discussion Paper. Key roles in industry training systems. Retrieved from https://www.education.govt.nz/assets/Documents/Ministry/consultations/Revi ew-of-industry-training/DiscussionDocumentIndustryTrainingReview.pdf

Ministry of Education of New Zealand. (2018). Education in New Zealand.

Retrieved from https://www.education.govt.nz/ministry-of-education/ourrole-and-our-people/education-in-nz/\#primary

Ministry of Education of New Zealand. (2019). Tertiary Education Strategy 2014 2019. Retrieved from https://www.education.govt.nz/furthereducation/policies-and-strategies/tertiary-education-strategy/

Misko, J., Korbel, P., \& Blomberg, D. (2017). VET in Schools students: characteristics and post-school employment and training experiences Retrieved from Adelaide:

https://www.ncver.edu.au/_data/assets/pdf_file/0037/887716/VET-inSchools-students-characteristics-and-post-school-employment-and-trainingexperiences.pdf

Morgan, M. (2010). The Australian Blueprint for Career Development. Australia, Commonwealth of Australia, Canberra Retrieved from https://docs.education.gov.au/system/files/doc/other/australian_blueprint_for career_development.pdf

Morillo, E. (2000). Reformas Educativas en el Perú del Siglo XX (Educational Reforms in Peru in the 20th Century). Revista Iberoamericana de Educación.

National Centre for Vocational Education Research. (2019). About us. Retrieved from https://www.ncver.edu.au/about-ncver/about-us

New Zealand Productivity Commission. (2017). New models of tertiary education: Final Report. Retrieved from https://www.productivity.govt.nz/sites/default/files/New\%20models\%20of\% 20tertiary\%20education\%20FINAL.pdf

OECD. (2014a). Employment and Skills Strategies in Canada. Retrieved from https://www.oecd-ilibrary.org/employment/employment-and-skills-strategiesin-canada 9789264209374-en

OECD. (2014b). Employment and Skills Strategies in Canada, OECD Reviews on Local Job Creation. Retrieved from https://www1.oecd.org/publications/employment-and-skills-strategies-incanada-9789264209374-en.htm

OECD. (2015). Education Policy Outlook: Canada. Retrieved from http://www.oecd.org/education/EDUCATION\%20POLICY\%20OUTLOOK \%20CANADA.pdf

OECD. (2016). Employment and Skills Strategies in Saskatchewan and the Yukon, Canada. Retrieved from Paris: https://www.oecd.org/canada/employment- 
and-skills-strategies-in-saskatchewan-and-the-yukon-canada9789264259225-en.htm

OECD. (2017). Small, Medium, Strong.Trends in SME Performance and Business Conditions. Retrieved from Paris: https://www.oecd.org/industry/smallmedium-strong-trends-in-sme-performance-and-business-conditions9789264275683-en.htm

OECD Development Centre. (2016). Avanzando hacia una mejor educación para Perú (Moving towards a better education for Peru). Retrieved from https://www.oecd.org/dev/Avanzando-hacia-una-mejor-educacion-enPeru.pdf

OECD Reviews of Vocational education and training. (2014). Skills Beyond School. Synthesis Report. Retrieved from http://www.oecd.org/education/innovationeducation/skillsbeyondschool.htm

OECD. (2019). Better Life Indicator. Retrieved from http://www.oecdbetterlifeindex.org/\#/11111111111

Olaechea, P. (2018). ¿Seguir o no seguir? (Go further or not?)El Comercio. Retrieved from https://elcomercio.pe/opinion/colabouradores/seguir-seguirdiversificacion-productiva-cites-pedro-olaechea-noticia-510794

Organización de las Naciones Unidas para el Desarrollo Industrial. (2016). Brechas y oportunidades de desarrollo para centros de innovación productiva y transferencia tecnológica (CITE) en Perú: Análisis independiente de los CITE Madera Lima, CITE Cuero y Calzado Lima y CITE Agroindustrial Ica (Gaps and development opportunities for centers of productive innovation and technology transfer (CITE) in Peru: Independent analysis of the CITE Wood Lima, CITE Leather and Footwear Lima and CITE Agroindustrial Ica). Retrieved from Lima: https://www.unido.org/sites/default/files/files/201808/Brechas_y_Oportunidades_de_Desarrollo_para_CITE_ONUDI_2016_1.p df

Pawson, R., \& Tilley, N. (1997). Realistic Evaluation. London: SAGE Publications.

Peru Info. (2018). La importancia comercial de la Alianza del Pacífico (The commercial importance of the Pacific Alliance). Retrieved from https://peru.info/es-pe/comercio-exterior/noticias/7/34/la-importanciacomercial-de-la-alianza-del-pacifico

Plan Nacional de Diversificación Productiva (National Productive Diversification Plan), Decreto Supremo No 004-2014 - PRODUCE C.F.R. (2014).

Ponteencarrera.pe. (2018). Retrieved from https://www.ponteencarrera.pe/sobrenosotros

Proyecta tu futuro. (2018). Retrieved from http://proyectatufuturo.trabajo.gob.pe/index

Queensland Government. (2018). Vocational Education and Training in Schools (VETiS). Retrieved from https://training.qld.gov.au/providers/funded/vetis

Quijano, A. (2000). Colonialidad del poder, eurocentrismo y América Latina (Coloniality of power, Eurocentrism and Latin America). In La colonialidad del saber: eurocentrismo y ciencias sociales. Perspectivas latinoamericanas. Argentina: CLACSO.

Red Seal. (2019). Red Seal Program. Retrieved from http://www.redseal.ca/about/pr.4gr.1m-eng.html 
Reglamento de organización y funciones del Ministerio de Educación (Regulation of organization and functions of the Ministry of Education). Decreto Supremo $\mathrm{N}^{\mathrm{o}}$ 001-2015-MINEDU. (2015).

Reglamento de la Ley No 30512, Ley de Institutos y Escuelas de Educación Superior y de la Carrera Pública de sus Docentes (Law on Institutes and Schools of Higher Education and Public Teaching Career), Decreto Supremo No 0102017-MINEDU C.F.R. (2017).

Reglamento de Organización y Funciones del Ministerio de la Producción. Decreto Supremo No 002-2017-PRODUCE, (2017).Rios, M. (2018a). El 80\% de jóvenes menores de 24 años trabaja en el sector informal (80\% of young people under 24 work in the informal sector). Diario Gestion. Retrieved from https://gestion.pe/economia/management-empleo/80-jovenes-menores-24anos-sector-informal-227998

Rios, M. (2018b). Produce: El 45\% de las empresas revela problemas para contratar personal técnico (45\% of companies reveal problems in hiring technical employees). Diario Gestión. Retrieved from

https://gestion.pe/economia/produce-45-empresas-revela-problemascontratar-personal-tecnico-245343

Rubio Barceló, E. (2002). Nuevas herramientas conceptuales para el análisis de políticas públicas: la literatura sobre difusión y transferencia de políticas (New conceptual tools for public policy analysis: literature on dissemination and policy transfer). Gestión y Análisis de Políticas Públicas, 25.

Sahlberg, P. (2007). Secondary education in OECD countries: Common challenges, differing solutions. Retrieved from https://www.etf.europa.eu/sites/default/files/m/C12578310056925BC125738 50034415B NOTE78HD6G.pdf

Santos-Rego, M. (2000). El pensamiento complejo y la pedagogía. Bases para una teoría holística de la educación (Complex thinking and pedagogy. Bases for a holistic theory of education). Estudios Pedagógicos, 26.

Sevilla B., M. P., \& Trucco, D. (2017). Panorama de la educación técnica profesional en América Latina y el Caribe (Overview of professional technical education in Latin America and the Caribbean). Retrieved from https://repositorio.cepal.org/bitstream/handle/11362/40920/1/S1601350 es.pd $\mathrm{f}$

Tertiary Education Commission. (2018). Our role. Retrieved from https://www.tec.govt.nz/about-us/what/our-role/

Tertiary Education Commission. (2019). Monitoring performance and reporting. Retrieved from https://www.tec.govt.nz/about-us/how-we-work/monitoringperformance/

The Canadian Standards \& Guidelines for Career Development Practitioners (S\&Gs). (2019). Understanding the S\&Gs. Retrieved from http://career-devguidelines.org/the-standards-guidelines/understanding-the-sgs/

The National LifeWork Centre. (2019). Blueprint for Life/Work Design. Retrieved from https://www.lifework.ca/lifework/blueprint.html

The New Zealand Qualifications Authority. (2018). The New Zealand Qualifications Framework. In T. N. Z. Q. Authority (Ed.).

UNESCO Institute for Statistics. (2012). International Standard Classification of Education. ISCED 2011. Retrieved from http://uis.unesco.org/sites/default/files/documents/international-standardclassification-of-education-isced-2011-en.pdf 
UNEVOC. (2012). World TVET Database New Zealand. Retrieved from https://unevoc.unesco.org/wtdb/worldtvetdatabase_nzl_en.pdf

UNEVOC. (2013). World TVET Database Canada. Retrieved from https://unevoc.unesco.org/wtdb/worldtvetdatabase_can_en.pdf

UNEVOC. (2018). TVET Country Profile. Australia. Retrieved from https://unevoc.unesco.org/wtdb/worldtvetdatabase_aus_en.pdf

Vera, R. (2013). Productividad en el Perú. Evolución histórica y la tarea pendiente (Productivity in Peru. Historical evolution and the pending task). Revista Moneda. Retrieved from http://www.bcrp.gob.pe/docs/Publicaciones/RevistaMoneda/moneda-153/moneda-153-06.pdf

Walker, I., \& Aedo, C. (2012). Skills for the 21st Century in Latin America and the Caribbean. Retrieved from http://siteresources.worldbank.org/INTLACREGTOPLABSOCPRO/Resourc es/Skillsandemployability21stCentury.pdf

World Economic Forum. (2017). The Global Human Capital Report 2017. Retrieved from

http://www3.weforum.org/docs/WEF_Global_Human_Capital_Report_2017. pdf

World Bank. (2019). Rankings \& Ease of Doing Business Score. Retrieved from http://www.doingbusiness.org/en/rankings 


\section{Appendix}

\section{Figure 1: Governance of VET System}

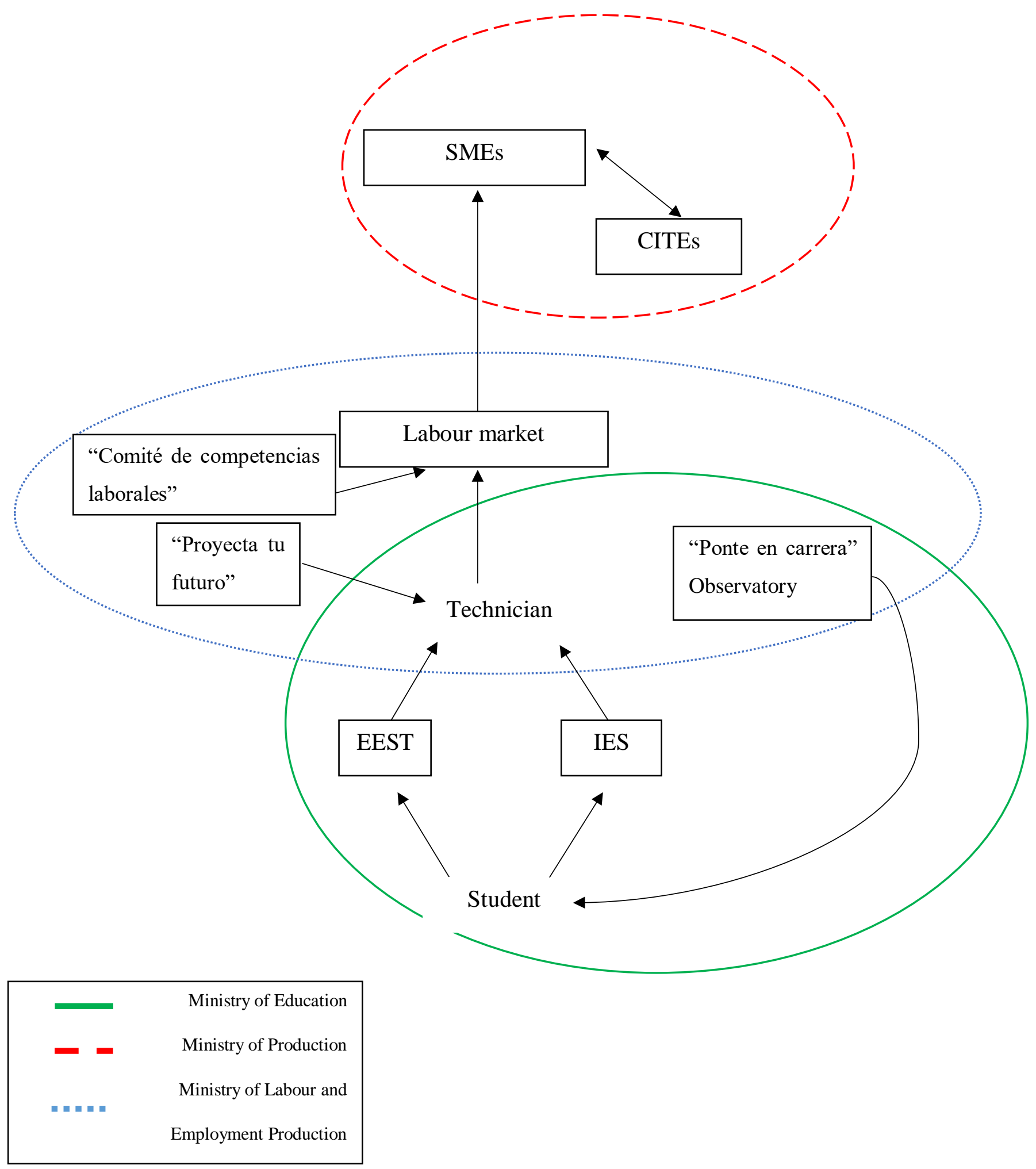


Figure 2: Peruvian Technical Education institutes

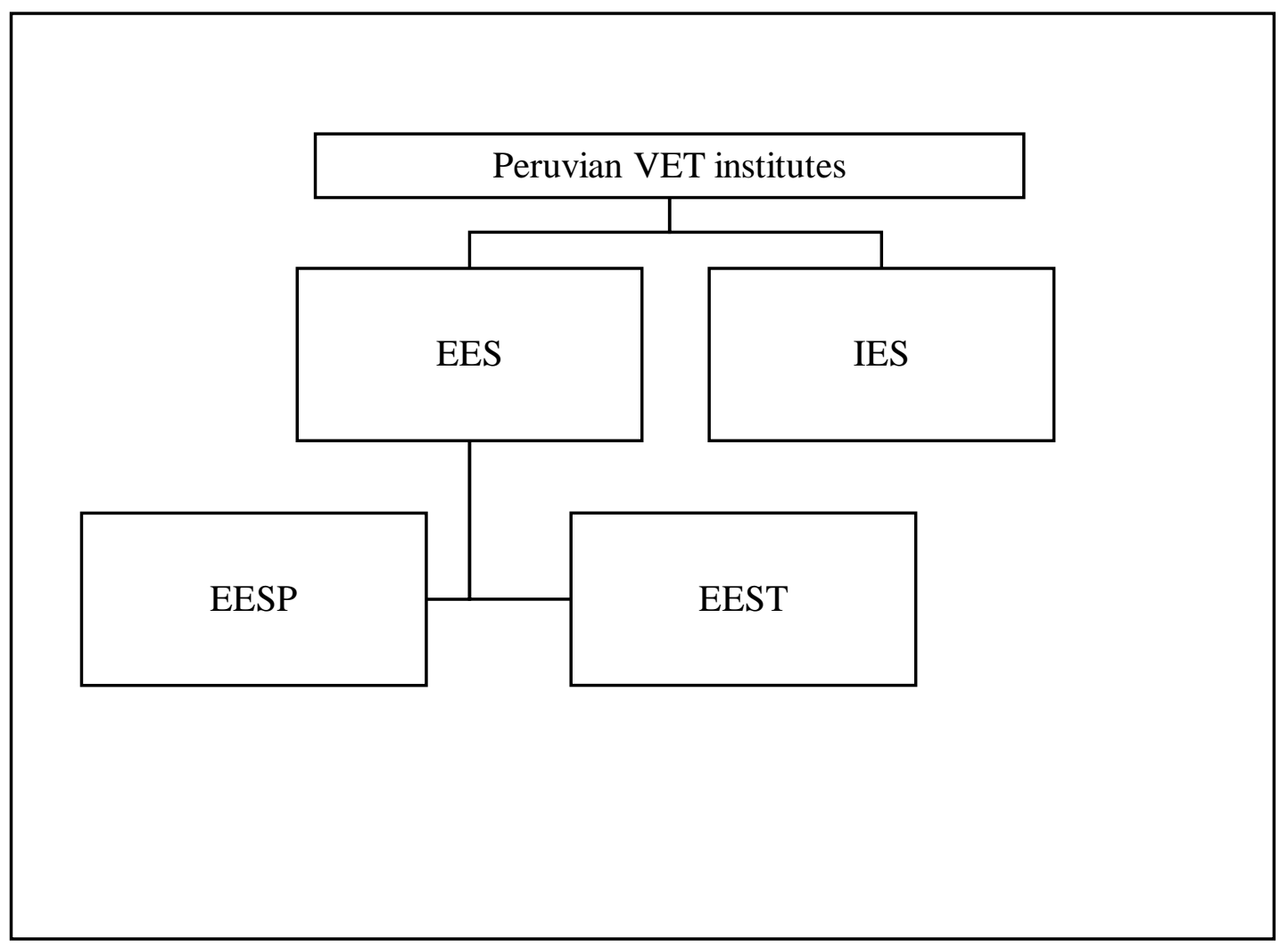


Figure 3: Proposal for a better governance of VET System

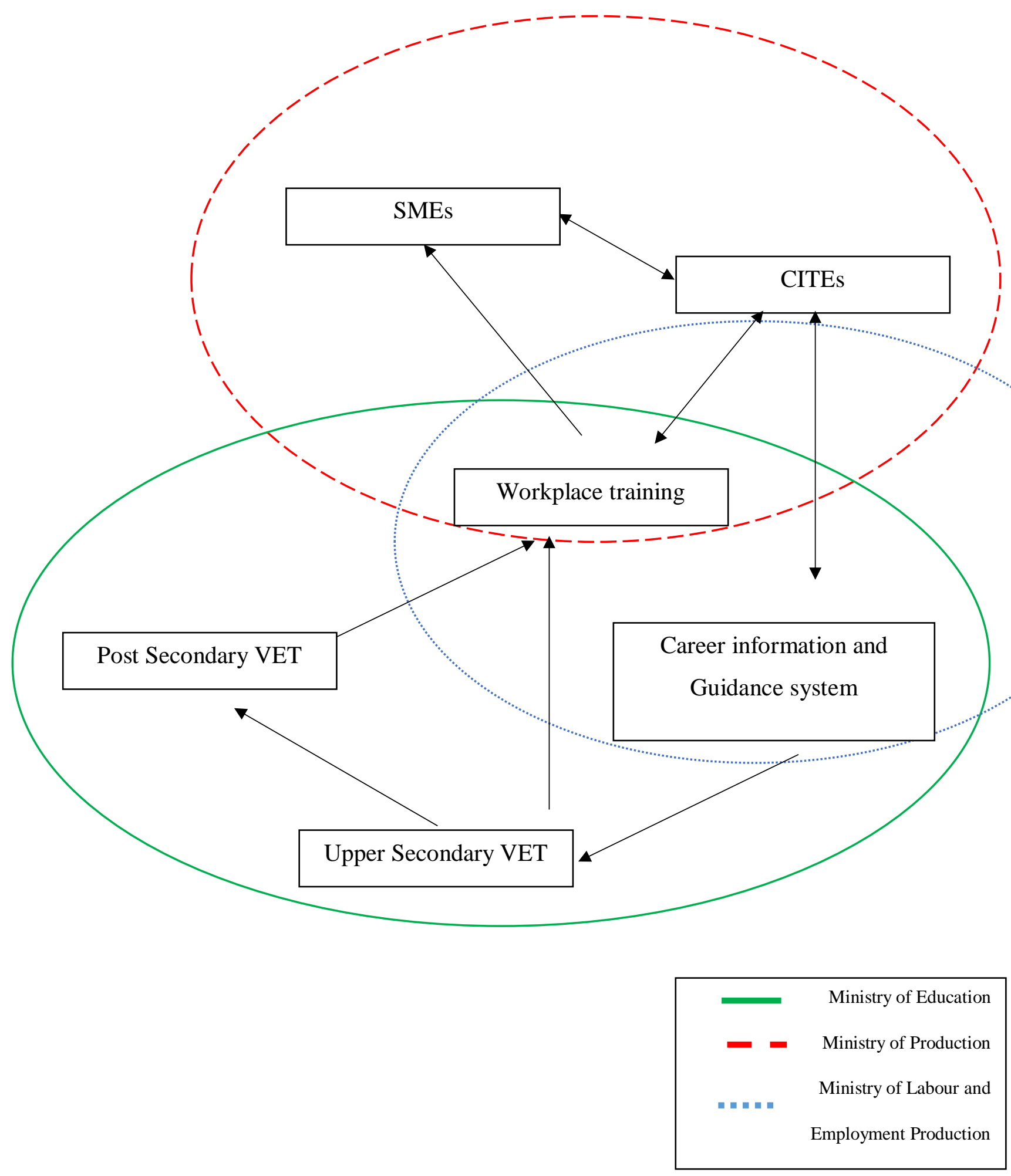


Figure 4: Proposal for an effective VET Peruvian system

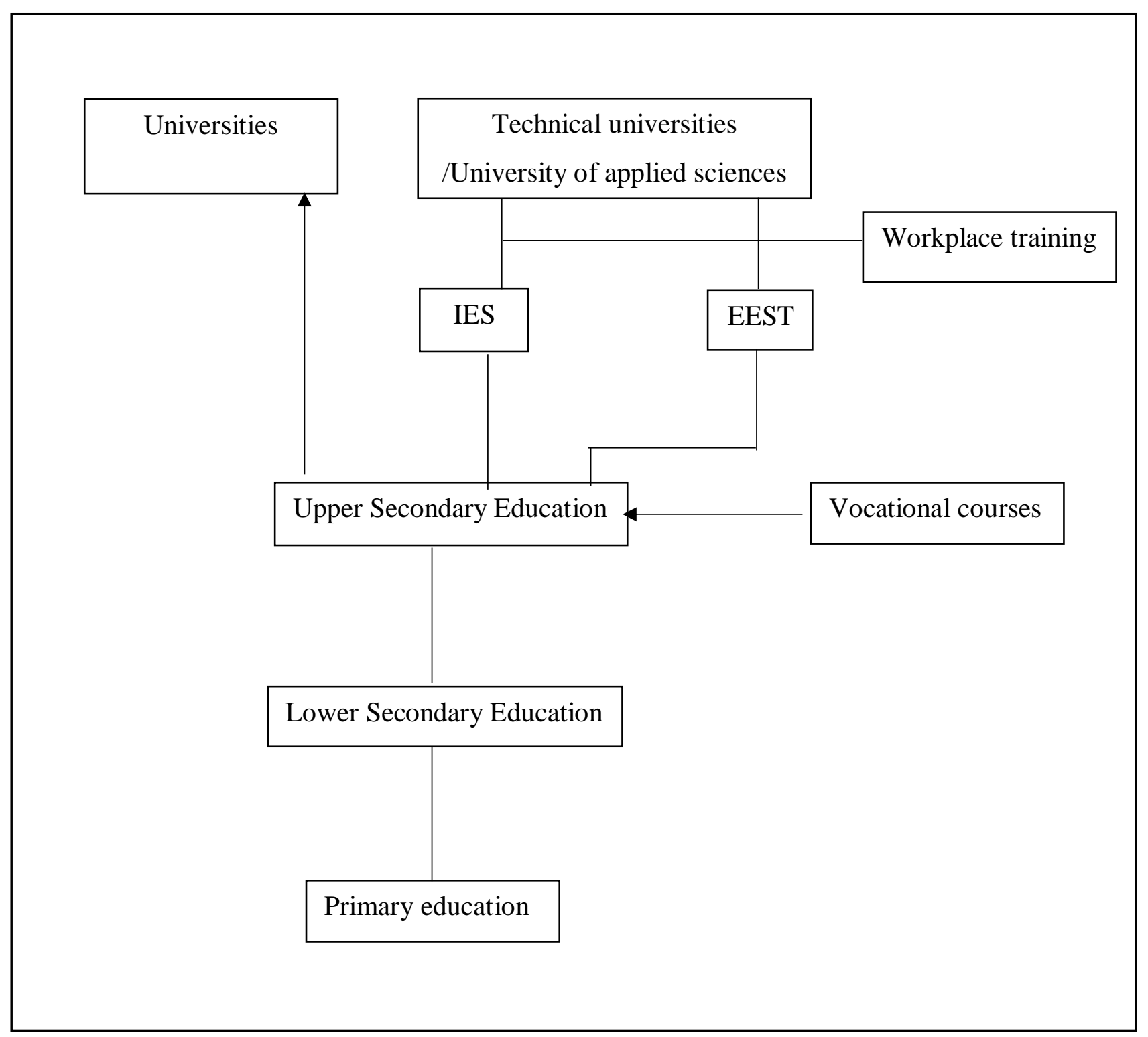




\section{Figure 5}

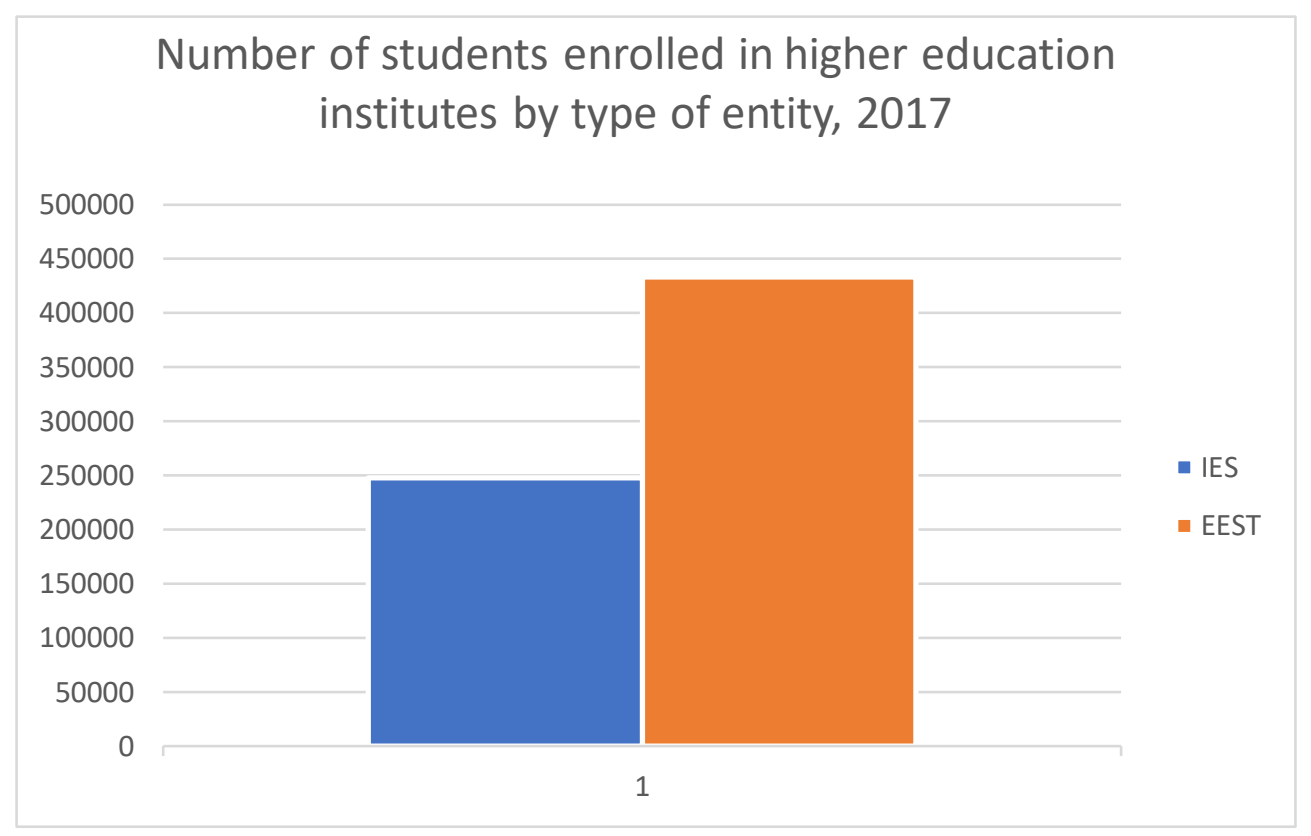

Source: National Institute of Statistics and Informatics, 2017.

\section{Figure 6}

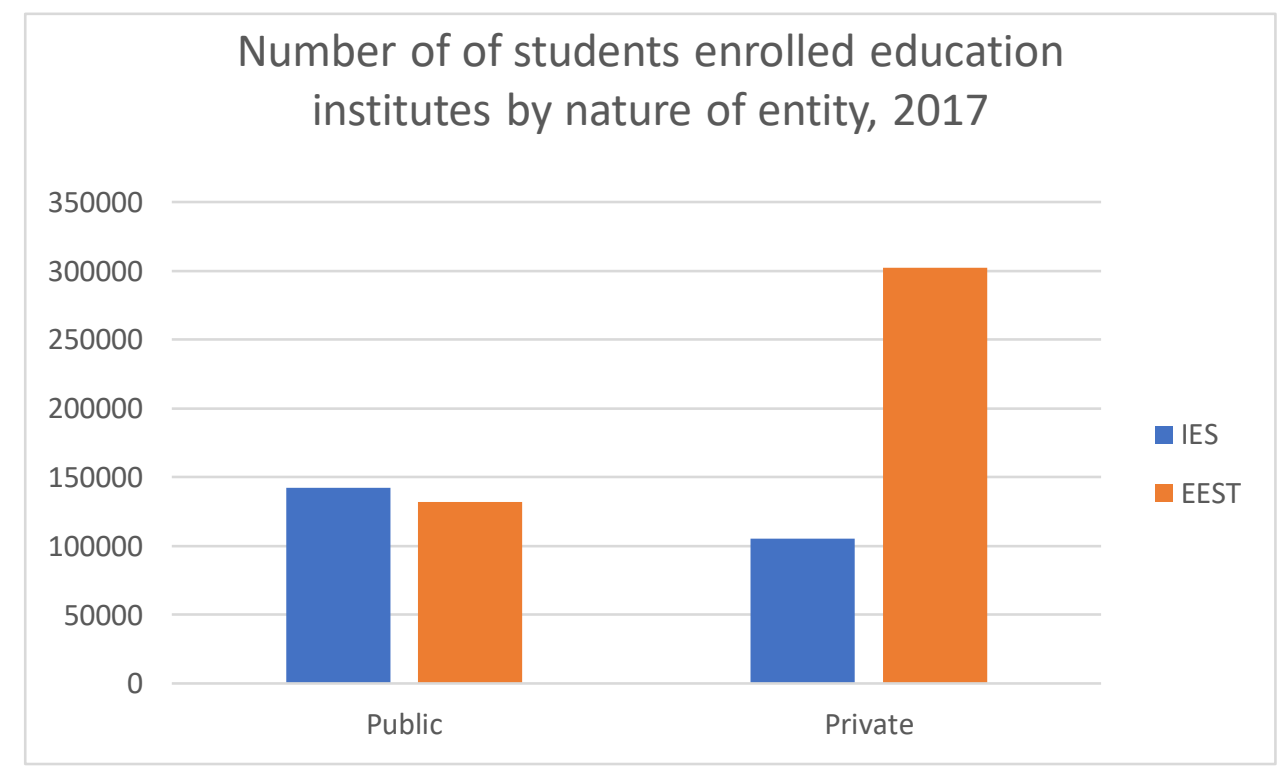

Source: National Institute of Statistics and Informatics, 2017. 


\section{Figure 7}

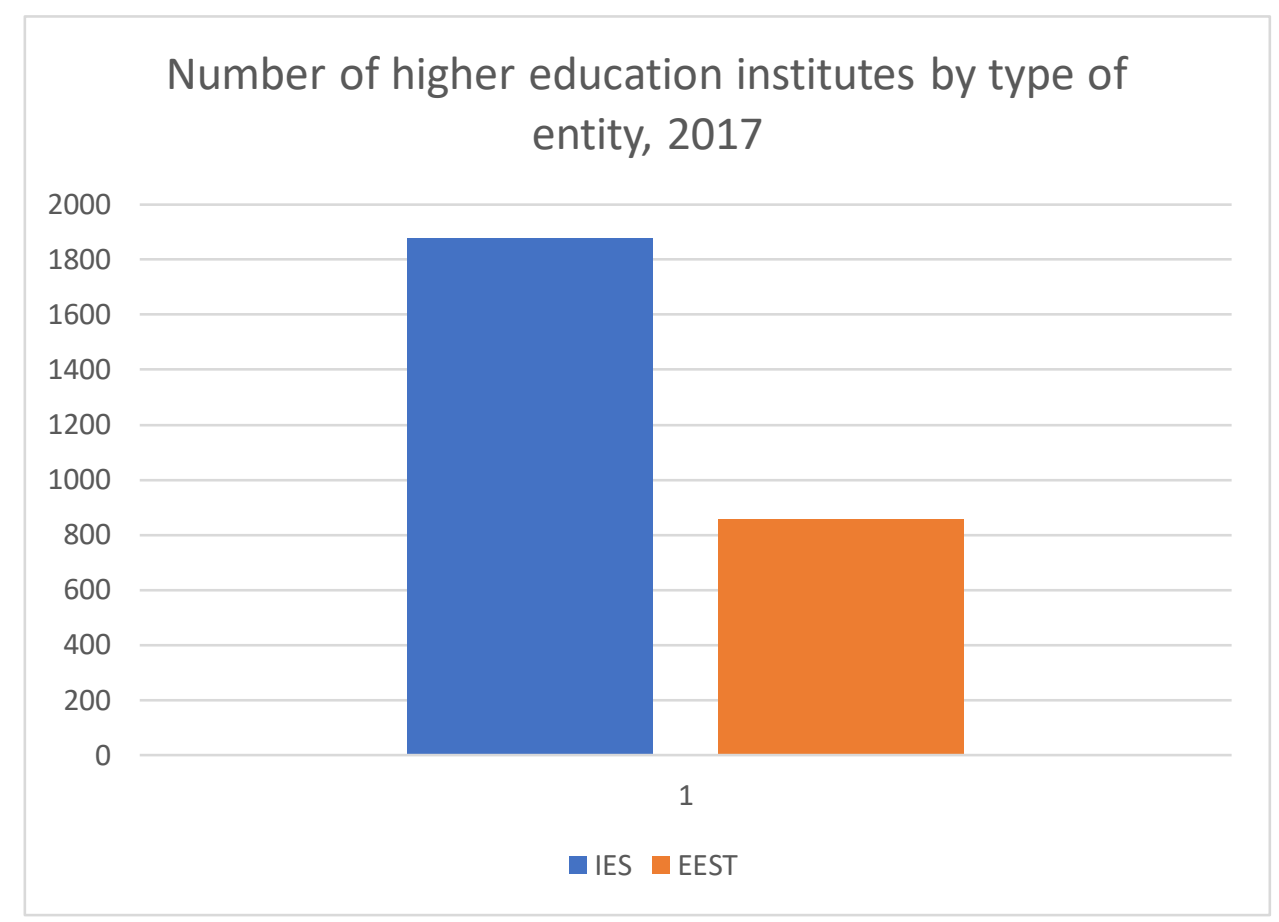

Source: National Institute of Statistics and Informatics, 2017.

\section{Figure 8}

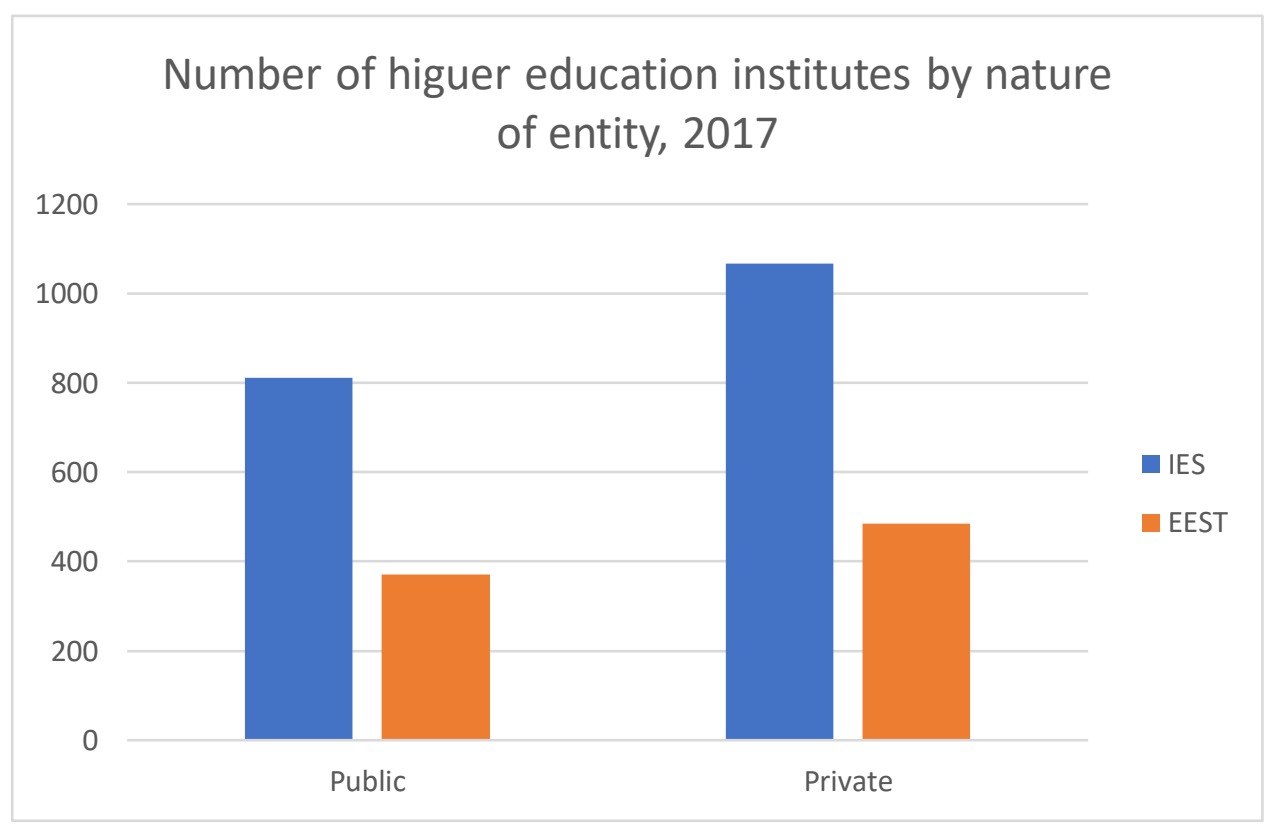

Source: National Institute of Statistics and Informatics, 2017. 